UDC 331.1

JEL Classification: 030, M50

http://doi.org/10.21272/mmi.2019.1-28

\title{
Ewa Mazur-Wierzbicka
}

Prof., University of Szczecin, Poland

\section{HUMAN RESOURCES AS FUNDAMENTAL ELEMENT DETERMINING THE DEVELOPMENT OF INNOVATION}

\begin{abstract}
The issues of innovation and innovativeness have been addressed by a number of papers, both theoretical and those including research results. However, there are few studies devoted to the analysis of factors determining innovation. According to the Author, human resources are one of its key elements. This was the premise for taking up reflections in this paper on innovation in the context of its main determinant, i.e. human resources. Innovation is one of the most important directions of the Union's policy and is supposed to be a basis of EU Member States' lasting economic growth and improvement of economic and social conditions. In view of the above, the paper adopts the countries of the European Union as the subject matter of analyses and particular emphasis is given to Poland. The paper's main purpose is to assess the level of human capital - a fundamental element determining the development of innovation - in Poland against the background of the European Union countries. The paper also sets detailed objectives: an assessment of the innovation level in Poland against the countries of the European Union using the European Summary Innovation Index (SII) and the Global Innovation Index (GII); an assessment of the level of human capital in the context of innovation in Poland against the European Union countries using components of the SII; an assessment of the level of human capital in the context of innovation in Poland against the European Union countries using components of the Gll; an assessment of the level of human capital in the context of innovation in Poland against the European Union countries using components of the Human Resources for Science and Technology (HRST) with its components. The research methodology involves statistical analyses. The paper uses innovation-related indices (SII, GIl and HRST) and their components allowing the measurement of the human resources factor. The comparative analyses were based on descriptive distribution characteristics. Also, grouping of countries was performed adopting the EU average as the classification criterion. The geographical scope of the analyses includes 28 countries of the European Union (EU-28). The time horizon of the analyses covers the years 2010-2016. The year in which the European Commission presented the proposal of the Europe 2020 strategy was adopted as the beginning of the analyses. The analysis of the development of the SII and the GII shows significant diversification of the European Union countries in the level of innovation. The leaders include mainly the countries of Northern Europe. A similar trend is seen when assessing the EU countries in terms of the development of the human factor as a fundamental element determining the development of innovation. It is significant that most of the EU states both in 2010 and 2016 were classified in the same groups specifying the level of innovation as well as the level of human resources constituting a fundamental element determining the development of innovation. Polish economy features a low level of innovation-related indicators as well as human resources indicators in the context of innovation, both in comparison to EU innovation leaders and EU countries with a similar level of economic development, i.e. the Czech Republic, Hungary and Slovenia.
\end{abstract}

Keywords: innovation, human resources for science and technology, EU countries, Poland.

Introduction. One can see in the 21 st century a trend of shaping a new model far from the one based on raw materials, physical labour and simple investments, i.e. a model based on knowledge developed thanks to the intelligence of people and their energy, imagination and willingness to act that is the driving force behind the technical, scientific and technological progress.

One of the key factors determining innovation and affecting economic development is human resources, more broadly: human capital (cf. Dakhli, De Clercq 2004; Benhabib, Spiegel 2005; Ang et. al. 2011; Danquaha, Amankwah-Amoahb 2017). Innovation is the effect of people's activity (Pater, Lewandowska 2015). It is heavily dependent on their knowledge, professional experience, skills and qualifications (cf. Del Giudice et al. 2018). When doing a literature review, one can notice a small number of publications addressing individual components determining innovation. This was the main premise for

Cite as: Mazur-Wierzbicka, E. (2019). Human Resources as Fundamental Element Determining the Development of Innovation. Marketing and Management of Innovations, 1, 335-356. http://doi.org/10.21272/mmi.2019.1-28 
the paper to take up reflections on innovation in the context of its main determinant, i.e. human resources.

The literature features no single definitional approach to innovation or innovativeness (e.g. Barnett, 1953; Schumpeter, 1960; Drucker, 1992; Griffin, 2007, European..., 2012, p. 4 Schippers et al., 2012, p. 3; Tan, Nasurdin 2010; Birkinshaw et al. 2011; Hecker, Ganter 2013) both of the organization and of the economy. In general, innovativeness means the ability to create broadly understood innovations. It involves active involvement in innovative processes and undertaking activities in this direction (Nowakowska, 2009). Within the framework of issues analyzed in the paper, it can be assumed that innovation of the economy is the ability and willingness of economic entities to constantly search for and use in economic practice the results of scientific research and research and development works, new concepts, ideas and inventions, to improve and develop the used technologies of material and nonmaterial (services) production, to introduce new methods and techniques in organization and management, to improve and develop infrastructure and knowledge resources. It should also be noted which is important on account of reflections contained in this study - that innovation is strictly related to the resources held, but also to the ability to use them (Niedzielski, 2005, pp. 74-75).

Not only the definition approach, but also the measurement of innovation is a very complex issue that arouses much controversy. It results from the multistage nature and complexity of the process of creating and implementing innovative solutions. Therefore, a series of indicators included in collective indices is most frequently used for the diagnosis and international comparisons of innovativeness of economies (cf. Delgado-Marquez, Garcia-Velasco 2018; Roszko-Wojtowicz, Bialek 2017; Kudryavtseva et al. 2016). They are used to construct rankings defining the position of a given country in terms of innovative activity against other economies.

The paper's main purpose is to assess the level of human capital - a fundamental element determining the development of innovation - in Poland against the background of the European Union countries. The paper also sets detailed objectives:

1. An assessment of the innovation level in Poland against the countries of the European Union using the European Summary Innovation Index (SII) and the Global Innovation Index (GII).

2. An assessment of the level of human capital in the context of innovation in Poland against the European Union countries using components of the SII.

3. An assessment of the level of human capital in the context of innovation in Poland against the European Union countries using components of the GII.

4. An assessment of the level of human capital in the context of innovation in Poland against the European Union countries using components of the Human Resources for Science and Technology (HRST) with its components.

The paper was based on in-depth literature studies and an analysis of secondary data, i.e. the development of the Summary Innovation Index, Global Innovation Index and the Human Resources in Science and Technology indicator.

The geographical scope of the analyses includes 28 countries of the European Union (EU-28). The time horizon of the analyses covers the years 2010-2016. The year in which the European Commission presented the proposal of the Europe 2020 strategy was adopted as the beginning of the analyses. Increasing innovation of the economies of EU member states has become one of the main tasks included in the Europe 2020 strategy. Poland, like other new EU Member States, has the most to catch up with in this area.

Innovations in the modern world are a key source of rapid development of countries and their societies. Especially in the $21^{\text {st }}$ century an increase in the importance of innovation in economic processes is being observed. This process refers to many spheres of life, affecting not only the dynamics of development, but also the perception of future economic and social trends. The pace of progress and development of innovation in the economy is a determinant of the competitiveness of countries, regions and economic 
entities, but also the reason for the diversification of their level of activity in international rivalry (Pascu et al. 2015).

Pro-innovative activities are carried out on a large scale both by the governments of individual countries and by the European Union (Gasz, 2015). One of the most important EU activities aimed at increasing competitiveness and innovation was the Lisbon Strategy announced in 2000 (Romanowska, 2014). According to the assumptions adopted in it, by 2010 the EU economy was to become the most competitive and dynamically developing economy in the world, based on knowledge, capable of maintaining sustainable economic growth, creating more better jobs and maintaining social cohesion. This goal was to be achieved among others by increasing spending on research and development in Member States to $3 \%$ of GDP. Unfortunately, it has not been achieved.

After the completion of the implementation of the Lisbon strategy, another strategy that sets the main directions of development of the European Union until 2020 is the Strategy for smart, sustainable and inclusive growth - Europe 2020 (Europe 2020 strategy) (Mazur-Wierzbicka, 2012, Wiatrak 2016; Paova, Vaclavikova 2017). It assumed smart and sustainable development, increased number of jobs, and improvement of the standard of living, which should be conducive to social inclusion and define the direction of development of societies.

Smart growth is therefore one of the strategy's three pillars (along with inclusive growth and sustainable growth).

It means the development of a knowledge-based and innovation-based economy - growth that creates high added value, requires significant R\&D outlays and the application of mechanisms that foster rapid transmission of theoretical knowledge to business practice (cf. Kedaitis, Kedaitiene 2014; Carayannis, Grigoroudis 2016). Because a knowledge-based economy is impossible without adequately educated society, this priority also includes the development and improvement of the quality of education (Papadopoulou 2017; Dino, Sanchez 2017).

Each of the pillars was assigned the so-called flagship initiatives. Three initiatives were assigned to the smart growth pillar (Table 1).

Table 1. Initiatives of the smart growth priority of the Europe 2020 strategy

\begin{tabular}{|l|l|}
\hline \multicolumn{1}{|c|}{ Initiative } & \multicolumn{1}{c|}{ Description } \\
\hline Innovation Union & $\begin{array}{l}\text { The use of R\&D activity and innovation to solve the biggest problems (related } \\
\text { to, among others, climate change, energy, but also the aging of society) and } \\
\text { the liquidation of the gap between the world of science and the market. }\end{array}$ \\
\hline Youth on the move & $\begin{array}{l}\text { Enhancing the quality and attractiveness of European higher education in the } \\
\text { international arena by supporting mobility of students and young } \\
\text { professionals. Increased availability of positions in Member States for } \\
\text { candidates from across Europe and proper recognition of qualifications and } \\
\text { professional experience should be a concrete manifestation of this. }\end{array}$ \\
\hline $\begin{array}{l}\text { A Digital Agenda for } \\
\text { Europe }\end{array}$ & $\begin{array}{l}\text { Achieving lasting economic and social benefits from a unified digital market } \\
\text { based on ultra-fast Internet. }\end{array}$ \\
\hline
\end{tabular}

Source: compiled on the basis of: (European Commission, 2010).

On the basis of the priorities, the objectives of the strategy at the level of the entire European Union were determined, broken down into thematic areas. For the smart growth priority, they are included in Table 2.

It should be noted that the strategy adopted targets for spending on innovative activity, but it does not feature target indicators describing the effects of such activity, despite the fact that there are such formulations in the strategy suggesting the Community's strive to improve innovative efficiency, such as: «social innovations» or «closer links between the scientific, research and business spheres». 
Table 2. Compilation of the Europe 2020 strategy's targets for Poland and the EU-28. Target value and value for 2016

\begin{tabular}{|l|l|l|l|l|}
\hline \multicolumn{1}{|c|}{ Specification } & \multicolumn{2}{|c|}{$\mathbf{2 0 2 0}$ target } & \multicolumn{2}{c|}{$\mathbf{2 0 1 6}$} \\
\hline \multicolumn{1}{|c|}{ Aim/Country } & EU-28 & Poland & EU-28 & Poland \\
\hline Spending on R\&D (\% GDP) & $3.00 \%$ & $1.70 \%$ & $2.03 \%$ & $0.97 \%$ \\
\hline Early school leavers (\%) & $10.00 \%$ & $4.50 \%$ & $10.7 \%$ & $5.2 \%$ \\
\hline $\begin{array}{l}\text { Percentage of people aged 30-34 years old who have } \\
\text { completed tertiary education }\end{array}$ & $40 \%$ & $45 \%$ & $39.1 \%$ & $44.6 \%$ \\
\hline
\end{tabular}

Source: compiled on the basis of: (European Commission, 2010).

The data contained in Table 2 shows that all 3 indicators should reach the assumed targets for the EU-28 in 2020 (cf. Baneliene 2013; Paprotny 2016; Fura et al. 2017). The assumed value of the «Early school leavers (\%)» indicator for both the EU-28 and Poland has already been achieved. In the case of Poland in particular, the possibility to meet the goal of spending on R\&D ( $\%$ of GDP) in the amount of $1.7 \%$ raises doubts.

It is evident from the adopted initiatives under the smart growth priority as well as the main goals and indicators what an important place in the approach to innovation is occupied by human resources.

Research methodology. Performing a comparative analysis of the development of innovation and an element affecting its level - human resources in Poland against the EU countries was based on descriptive distribution characteristics. An analysis of dynamics was also carried out (the percentage relative onebase increase).

Taking into account the values of individual innovation-related indicators and indices (SII, GII) and the values of indicators and indices related to human resources as an element affecting the level of innovation (Human capital \& research along with its components within the GII; HRST and its components) for the European Union countries in 2010 and 2016, using the classification criterion adopted by the European Union (applied for assigning countries to an adequate level of innovation - the SII), they were classified in one of the 4 groups. Group 1 included countries with the highest level of the analyzed indicators and Group 4 - the lowest. In order to assign the EU countries, the paper adopted the following classification criteria:

Group IV - Member States where performance is more than $20 \%$ above the EU average,

Group III - Member States with a performance between $90 \%$ and $120 \%$ of the EU average,

Group II - Member States where performance is between $50 \%$ and $90 \%$ of the EU average,

Group I - Member States that show a performance level below $50 \%$ of the EU average.

Results. The assessment of innovation can be done using a variety of methods and measures. For the needs of the assessment of the innovation level mainly of the European Union states, the European Commission publishes annually the European Innovation Scoreboard (EIS) (the EIS reports have been published under the name «European Innovation Scoreboard» until 2009, as «Innovation Union Scoreboard» between 2010 and 2015, and again as «European Innovation Scoreboard» from 2016 onwards).

The Summary Innovation Index (SII adopts values from 0 to 1 , where the closer to 1 the index value, the higher the level of innovation of a given country) is used for the assessment of innovative achievements of European economies. The SII is calculated every year for each European Union Member State. The source of data is the Union's statistical office - Eurostat, Scopus and Thomson Reuters data bases as well as data bases of the EOCD and the UN (the principles of the indicator's structure are described in each of the annual «Innovation Union Scoreboard» reports up until the 2016 issue and in the 2017 European Innovation Scoreboard report).

The analysis of the SSI's formation shows significant diversification of the European Union states in the level of innovation (Fig. 2). 


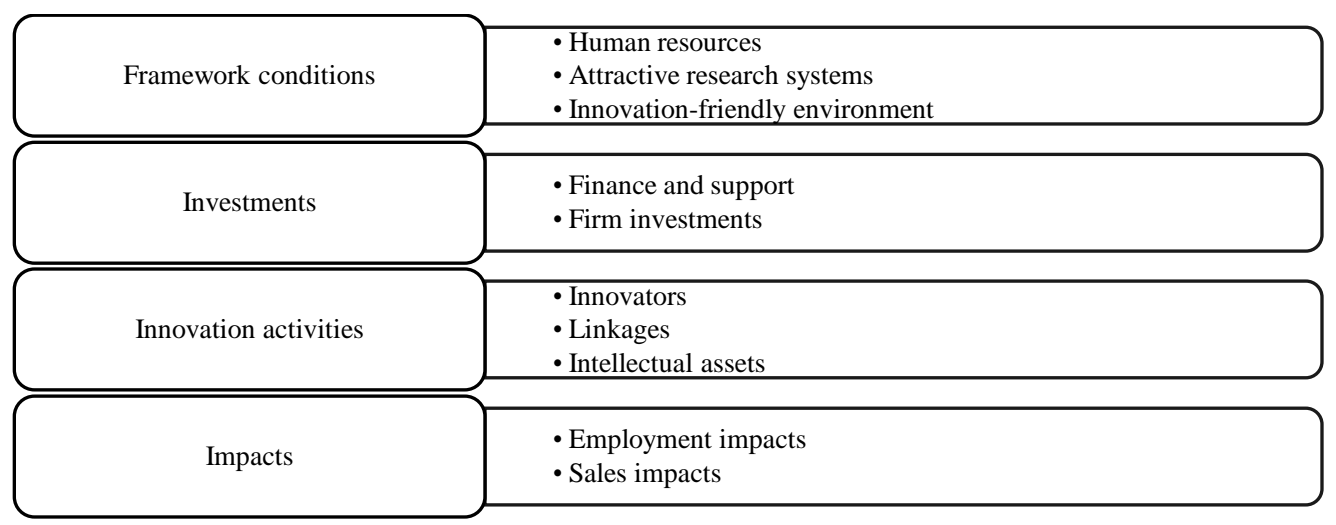

Figure 1. SII measurement -4 main groups and 10 dimensions (2016 data)

Source: (European Innovation Scoreboard, 2017).

As results from Figure 2, for the EU, performance between 2010 and 2016 improved by 2.0 percentage points. For $15 \mathrm{EU}$ countries (including Poland) an improvement in the SII was observed. An increase of $5 \%$ or more was achieved by: Lithuania $(21.0 \%)$, Malta $(12.2 \%)$, the United Kingdom $(11.7 \%)$, the Netherlands (10.4\%), Austria (8.9\%), Latvia (8.5\%) and Slovakia (8.0\%). In turn, an increase of below $5 \%$ was observed in: Ireland (3.5\%), France $(2.8 \%)$, Sweden $(2.3 \%)$, Poland $(2.0 \%)$, Belgium (1.4\%), Luxembourg (1.4\%), Greece $(0.7 \%)$ and Bulgaria $(0.1 \%)$. 10 EU countries observed a decrease in the SSI value between $(-0.2 \%)$ and $(-3.7 \%)$ (Slovenia $(-0.2 \%)$, Italy $(-0.2 \%)$, Croatia $(-1.4 \%)$, Spain $(-1.8 \%)$, Portugal $(-2.4 \%)$, Denmark $(-2.8 \%)$, Hungary $(-3.5 \%)$, the Czech Republic $(-3.5 \%)$, Estonia $(-3.6 \%)$ and Germany $(-3.7 \%)$. A drop of over $5 \%$ was reported in 3 countries: Finland $(-5.1 \%)$, Cyprus $(-12.7 \%)$ and Romania (-14.1\%).

The diversification of the level of innovation of EU countries allows for assigning them to four groups, i.e.: Innovation Leaders, Strong Innovators, Moderate Innovators, Modest Innovators (Table 3).

Table 3. EU Member States' innovation performance for 2010 and 2016

\begin{tabular}{|c|c|c|c|c|}
\hline \multirow{2}{*}{$\begin{array}{c}\text { Performance } \\
\text { groups }\end{array}$} & \multirow[t]{2}{*}{ Group } & \multirow[t]{2}{*}{ Classification criteria } & \multicolumn{2}{|c|}{ States belonging in the group } \\
\hline & & & 2010 & 2016 \\
\hline 1 & 2 & 3 & 4 & 5 \\
\hline $\begin{array}{l}\text { Innovation } \\
\text { Leaders }\end{array}$ & IV & $\begin{array}{l}\text { Member States } \\
\text { where performance is } \\
\text { more than } 20 \% \text { above } \\
\text { the EU average }\end{array}$ & $\begin{array}{l}\text { Denmark, Finland, } \\
\text { Germany Sweden }\end{array}$ & $\begin{array}{lr}\text { Denmark, } & \text { Finland, } \\
\text { Germany, } & \text { the } \\
\text { Netherlands, } & \\
\text { Sweden, the UK } & \\
\end{array}$ \\
\hline $\begin{array}{l}\text { Innovation } \\
\text { followers } \\
(2010) / S t r o n g \\
\text { Innovators } \\
(2016)\end{array}$ & III & \begin{tabular}{l}
\multicolumn{3}{l}{ Member States } \\
with a performance \\
between $90 \%$ and \\
$120 \%$ of the EU \\
average
\end{tabular} & $\begin{array}{lr}\text { Austria, } & \text { Belgium, } \\
\text { Cyprus, } & \text { Estonia, } \\
\text { France, } & \text { Ireland, } \\
\text { Luxembourg, } & \\
\text { Netherlands, } & \\
\text { Slovenia, the UK } & \end{array}$ & $\begin{array}{l}\text { Austria, Belgium, France, } \\
\text { Ireland, Luxembourg, } \\
\text { Slovenia }\end{array}$ \\
\hline $\begin{array}{l}\text { Moderate } \\
\text { Innovators }\end{array}$ & II & $\begin{array}{l}\text { Member States } \\
\text { where performance is } \\
\text { between } 50 \% \text { and } 90 \% \\
\text { of the EU average }\end{array}$ & $\begin{array}{l}\text { Czech Republic, } \\
\text { Greece, Hungary, Italy, } \\
\text { Malta, Poland, } \\
\text { Portugal, Slovakia and } \\
\text { Spain }\end{array}$ & $\begin{array}{l}\text { Croatia, Cyprus, the } \\
\text { Czech Republic, Estonia, } \\
\text { Greece, Hungary, Italy, } \\
\text { Latvia, Lithuania, Malta, } \\
\text { Poland, Portugal, } \\
\text { Slovakia, Spain }\end{array}$ \\
\hline
\end{tabular}


Continue table 3

\begin{tabular}{|l|c|l|l|l|}
\hline \multicolumn{1}{|c|}{$\mathbf{1}$} & $\mathbf{2}$ & \multicolumn{1}{c|}{$\mathbf{3}$} & \multicolumn{1}{c|}{$\mathbf{4}$} & \multicolumn{1}{c|}{$\mathbf{5}$} \\
\hline Modest & $\mathbf{I}$ & $\begin{array}{l}\text { Member States } \\
\text { that show a performance } \\
\text { level below 50\% of the EU, } \\
\text { average }\end{array}$ & $\begin{array}{l}\text { Bulgaria, } \\
\text { Lithuania, Romania }\end{array}$ & Bulgaria, Romania \\
\hline
\end{tabular}

Source: compiled on the basis of: (Innovation Union Scoreboard 2010; European Innovation Scoreboard, 2017).

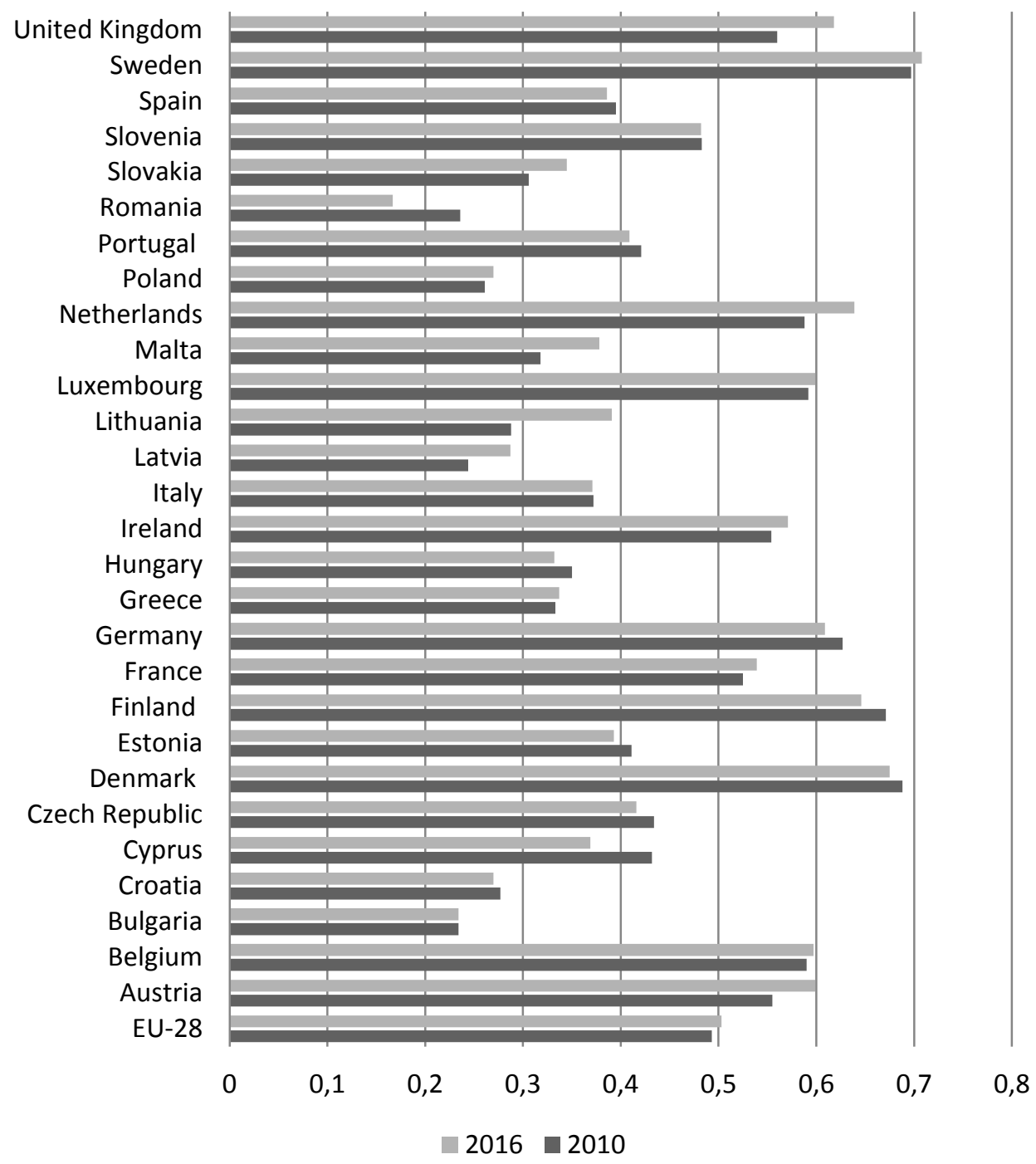

Figure 2. The SIl value in the European Union states in 2010 and 2016

Source: compiled on the basis of: (European Innovation Scoreboard, 2017). 
The distant position occupied by Poland against the background of the EU countries (Fig. 2) indicates the very low innovation potential of the country. In 2016, the value of the SII for Poland was higher only than the SII values for Bulgaria and Romania. In 2010, apart from being ahead of Bulgaria and Romania, it was ahead of Latvia. The overall value of the synthetic indicator is influenced by several dimensions, therefore attention should be paid to those in which the results achieved by Poland are the weakest. The values of indicators concerning individual dimensions of innovation allow for assessing the situation of Poland in detail against the background of countries that are leaders in particular dimensions (Figure 3 see Figure 1).

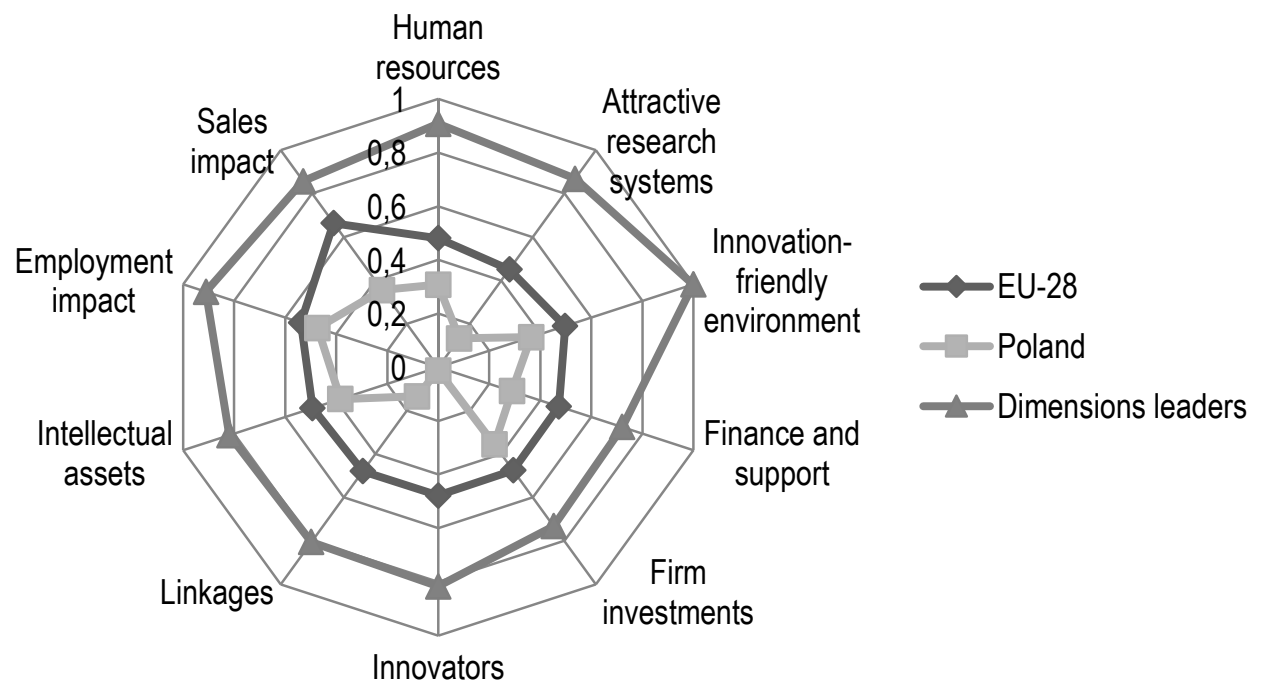

Figure 3. Poland's position against EU-28 in 10 Sll dimensions in 2016

Source: compiled on the basis of: (European Innovation Scoreboard, 2017).

On the basis of the results presented in Figure 3, the relatively favourable situation of Poland in 2016 is seen in the scope of: Employment impacts, Firm investments, and Innovation-friendly environment. In turn, the weakest results were achieved by Poland in the following dimensions: Innovators, Linkages, and Attractive research systems.

One of the dimensions of the SII is Human resources. This dimension is formed by 3 indicators. Their characteristic was presented in Table 4.

Table 4. Partial indicators of the Human Resources dimension included in the SIl for 2016

\begin{tabular}{|c|c|c|}
\hline Indicator & Definition numerator & Definition denominator \\
\hline 1 & 2 & 3 \\
\hline $\begin{array}{l}\text { New doctorate } \\
\text { graduates } \\
\text { per } 1000 \text { population } \\
\text { aged } 25-34\end{array}$ & Number of doctorate graduates & $\begin{array}{l}\text { Population between and } \\
\text { including } 25 \text { and } 34 \text { years }\end{array}$ \\
\hline $\begin{array}{l}\text { Percentage } \\
\text { population aged 25- } \\
34 \text { having completed } \\
\text { tertiary education }\end{array}$ & $\begin{array}{l}\text { Number of persons in age class with } \\
\text { some form of postsecondary education }\end{array}$ & $\begin{array}{l}\text { Population between and } \\
\text { including } 25 \text { and } 34 \text { years }\end{array}$ \\
\hline
\end{tabular}


Continue table 4

\begin{tabular}{|l|l|l|}
\hline 1 & \multicolumn{1}{|c|}{ 2 } & \multicolumn{1}{|c|}{3} \\
\hline Lifelong learning & $\begin{array}{l}\text { The target population for lifelong learning } \\
\text { statistics refers to all persons in private } \\
\text { households aged between } 25 \text { and } 64 . \text { The } \\
\text { information collected refers to all }\end{array}$ & $\begin{array}{l}\text { Total population of the same } \\
\text { age group, excluding those } \\
\text { who did not answer the } \\
\text { question concerning } \\
\text { participation in (formal and } \\
\text { non-formal) education and }\end{array}$ \\
& $\begin{array}{l}\text { education or training, whether or not } \\
\text { relevant to the respondent's current or } \\
\text { possible future job. Data is collected } \\
\text { through the EU labour force survey (LFS). } \\
\text { The reference period for the participation }\end{array}$ & \\
& in education and training is the four weeks \\
& preceding the interview as is usual in the & \\
& & \\
& LFS.
\end{tabular}

Source: (European Innovation Scoreboard, 2017).

One needs to point out the changes done in 2016 to the structure of the SII measurement in the «Human Resources» dimension compared to 2010: the «Population aged 30-34 with tertiary education» indicator was replaced by the «Population aged 25-34 with tertiary education». In addition, the «Youth with at least upper secondary education» indicator was removed. The «Lifelong learning» indicator was introduced in its place.

As results from Figure 4, comparing 2016 to 2010, the analyzed Human resources dimension for the EU-28 improved to a significant degree compared to other dimensions building the SII - an increase of 21 percentage points (a decrease was observed in 3 dimensions: finance and support, innovators, linkages). It was possible due to the recorded increase in the value of all 3 indicators included in the "Human resources» dimension, and to the largest extent the value of the «Tertiary education» indicator increased (an increase of 23 percentage points).

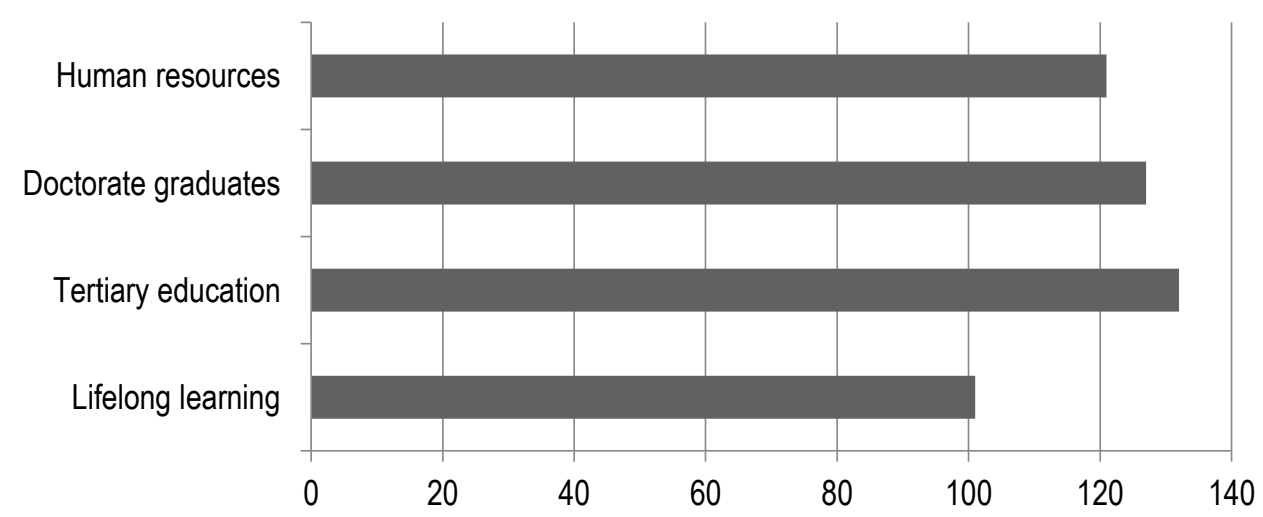

Figure 4. EU Performance change between 2010 and 2016 in the Human Resources dimension Note: Normalised scores in 2016 relative to those in $2010(=100)$

Source: compiled on the basis of: (European Innovation Scoreboard, 2017).

This state of affairs was possible because most of the EU-28 (unfortunately not Poland) reported relatively satisfactory results in the «Human Resources» dimension in 2016. «Human Resources» was 
one of the few dimensions usually classified as so-called relative strengths of the innovation system of individual countries.

Analyzing the data collected in Table 5 , it is evident that the results obtained by individual countries in the Human Resources dimension to a large extent are identical with assigning individual countries to one of the four performance groups.

Table 5. Human Resources indicators of the European Union by countries, 2016

\begin{tabular}{|c|c|c|c|c|}
\hline Countries & $\begin{array}{l}\text { Composite } \\
\text { Index }\end{array}$ & $\begin{array}{c}\text { New doctorate } \\
\text { graduates }(\% 0 \\
\text { population aged } \\
25-34)\end{array}$ & $\begin{array}{c}\text { Percentage } \\
\text { population aged } \\
\text { 25-34 having } \\
\text { completed } \\
\text { tertiary } \\
\text { education }\end{array}$ & $\begin{array}{c}\text { Percentage } \\
\text { population aged } \\
\text { 25-64 participating } \\
\text { in lifelong learning }\end{array}$ \\
\hline Denmark & 0.91 & 3.24 & 45.30 & 27.70 \\
\hline Sweden & 0.89 & 2.91 & 47.30 & 29.60 \\
\hline Finland & 0.81 & 2.88 & 40.70 & 26.40 \\
\hline United Kingdom & 0.74 & 3.03 & 47.20 & 14.40 \\
\hline Netherlands & 0.69 & 2.26 & 45.20 & 18.80 \\
\hline Slovenia & 0.69 & 3.55 & 43.00 & 11.60 \\
\hline Ireland & 0.62 & 2.51 & 51.80 & 6.40 \\
\hline France & 0.62 & 1.70 & 44.00 & 18.80 \\
\hline Luxembourg & 0.58 & 1.01 & 51.50 & 16.80 \\
\hline Austria & 0.55 & 1.90 & 39.70 & 14.90 \\
\hline Spain & 0.50 & 1.91 & 41.00 & 9.40 \\
\hline Germany & 0.49 & 2.85 & 30.50 & 8.50 \\
\hline Estonia & 0.49 & 1.08 & 41.20 & 15.70 \\
\hline Lithuania & 0.49 & 1.12 & 54.90 & 6.00 \\
\hline Belgium & 0.48 & 1.79 & 44.30 & 7.00 \\
\hline EU-28 & 0.48 & 1.85 & 38.20 & 10.80 \\
\hline Portugal & 0.44 & 1.90 & 35.00 & 9.60 \\
\hline Cyprus & 0.44 & 0.55 & 56.30 & 6.90 \\
\hline Czech Republic & 0.39 & 1.68 & 32.60 & 8.80 \\
\hline Slovakia & 0.38 & 2.25 & 33.40 & 2.90 \\
\hline Latvia & 0.37 & 0.91 & 42.10 & 7.30 \\
\hline Greece & 0.34 & 1.13 & 41.00 & 4.00 \\
\hline Poland & 0.31 & 0.63 & 43.50 & 3.70 \\
\hline Croatia & 0.31 & 1.57 & 33.00 & 3.00 \\
\hline Italy & 0.30 & 1.53 & 25.60 & 8.30 \\
\hline Bulgaria & 0.29 & 1.48 & 32.80 & 2.20 \\
\hline Hungary & 0.26 & 0.96 & 30.40 & 6.30 \\
\hline Malta & 0.25 & 0.48 & 34.00 & 7.50 \\
\hline Romania & 0.20 & 1.45 & 24.80 & 1.20 \\
\hline
\end{tabular}

Source: European Innovation Scoreboard, 2017 
Considering, therefore, the development of the value of the «Human resources» dimension, it should be noted that out of the Innovation Leaders group in 2016 only Germany obtained a slightly less satisfactory result (0.49), the EU average: 0.48 . In the Strong Innovators group only Belgium achieved a result similar to the EU average (0.48), while the other countries in the group observed higher results: Austria (0.55), France (0.62), Ireland (0.62), Luxembourg (0.58), and Slovenia (0.69). Out of the countries included in the Moderate Innovators group, only Spain and Lithuania achieved results above the EU average ( 0.50 and 0.49 , respectively). In the Modest Innovators group, the worst result was obtained by Romania (0.20).

In 2016, Poland ranked $25^{\text {th }}$ among all EU countries in the Human Resources dimension, taking the value well below the EU-28 average. In the case of Poland's position in the partial indicators of the Human resources dimension, the following were observed in 2016: "New doctorate graduates $(\%$ of the population aged 25-34)»-26 th position, «Percentage population aged 25-34 having completed tertiary education» $-11^{\text {th }}$ position, «Percentage population aged 25-64 participating in lifelong learning» $-24^{\text {th }}$ position.

Assuming relative values (Tables 6a, 6b, 6c), comparing 2016 with 2010, it should be emphasized that only in Portugal there was a decrease in the value of the Human Resources dimension (by almost $9 \%$ ). The best results were observed for Denmark: an increase of $60.0 \%$, Slovenia: an increase of $59.7 \%$, Austria: an increase of $41.1 \%$, Bulgaria: an increase of $38.1 \%$ and Greece: an increase of $34.85 \%$, Croatia: an increase of $32.2 \%$, Ireland and Latvia: an increase of $31.3 \%$. The EU average increased in the discussed dimension in the analyzed period by $21.0 \%$.

Table 6a. Individual profiles for the EU Member States in the Human Resources dimension in 2010 and 2016. 2010 adopted as a basis

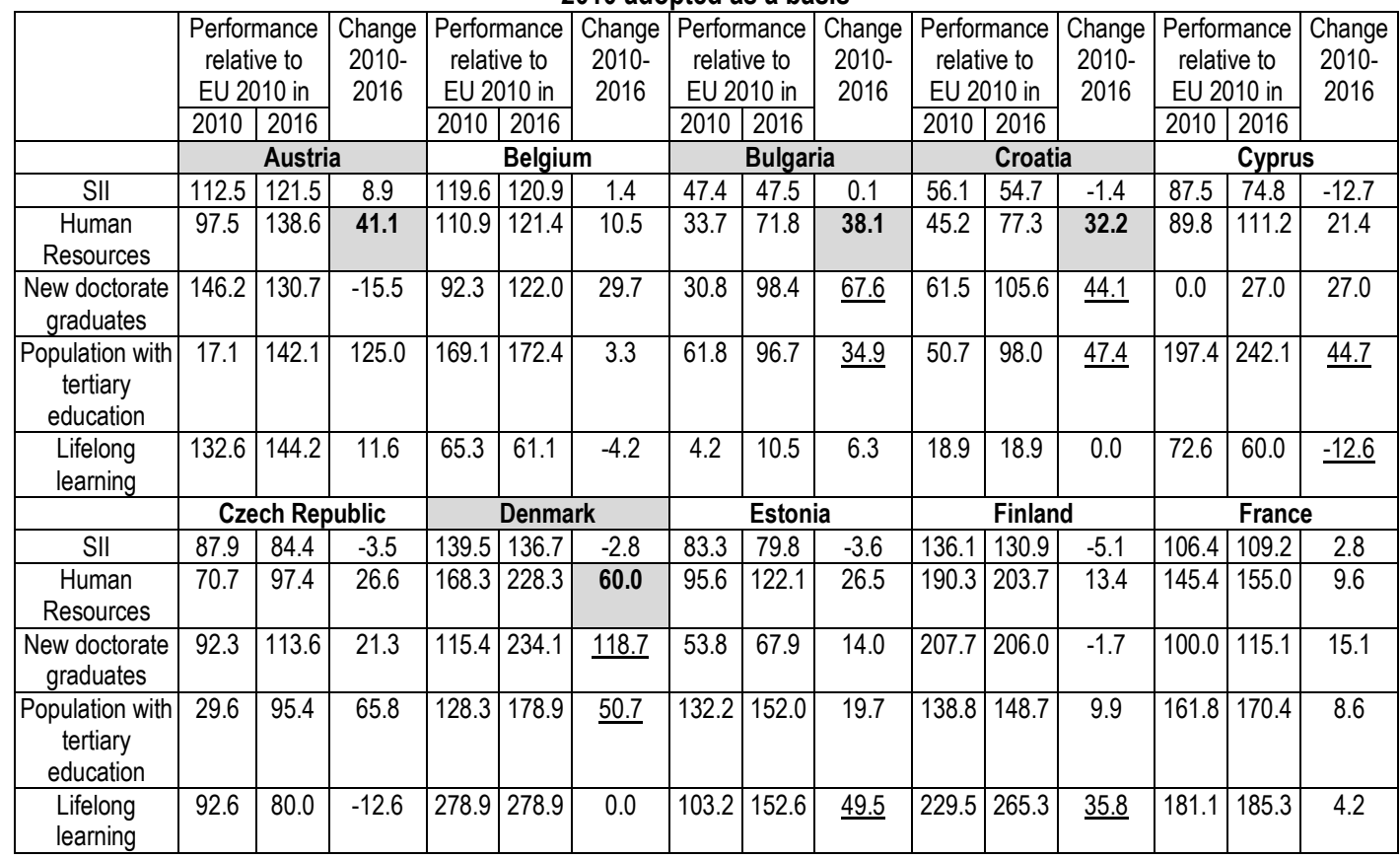

Source: compiled on the basis of European Innovation Scoreboard, 2017 
E. Mazur-Wierzbicka. Human Resources as Fundamental Element Determining the Development of Innovation

Table 6b. Individual profiles for the EU Member States in the Human Resources dimension in 2010 and 2016. 2010 adopted as a basis

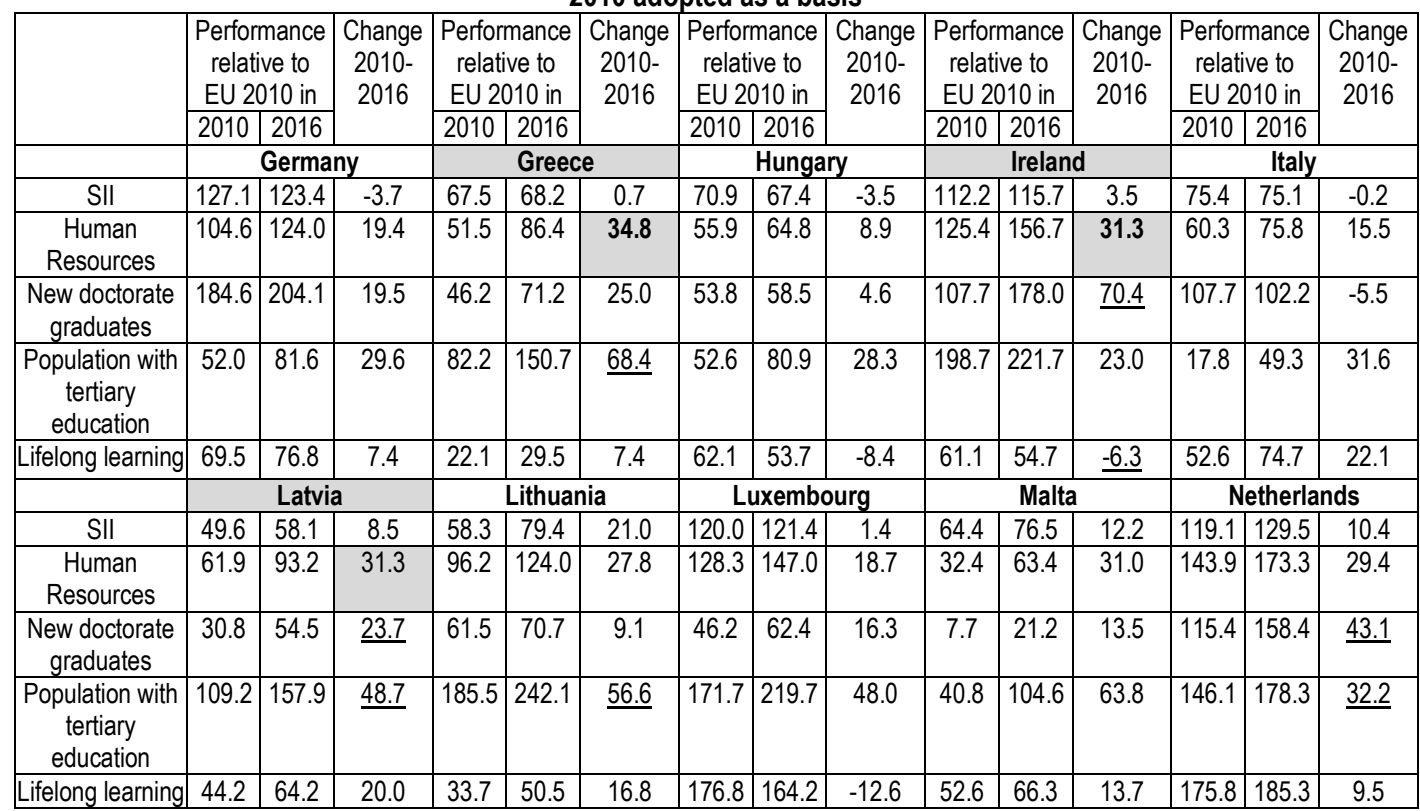

Source: compiled on the basis of European Innovation Scoreboard, 2017

Table 6c. Individual profiles for the EU Member States in the Human Resources dimension in 2010 and 2016. 2010 adopted as a basis

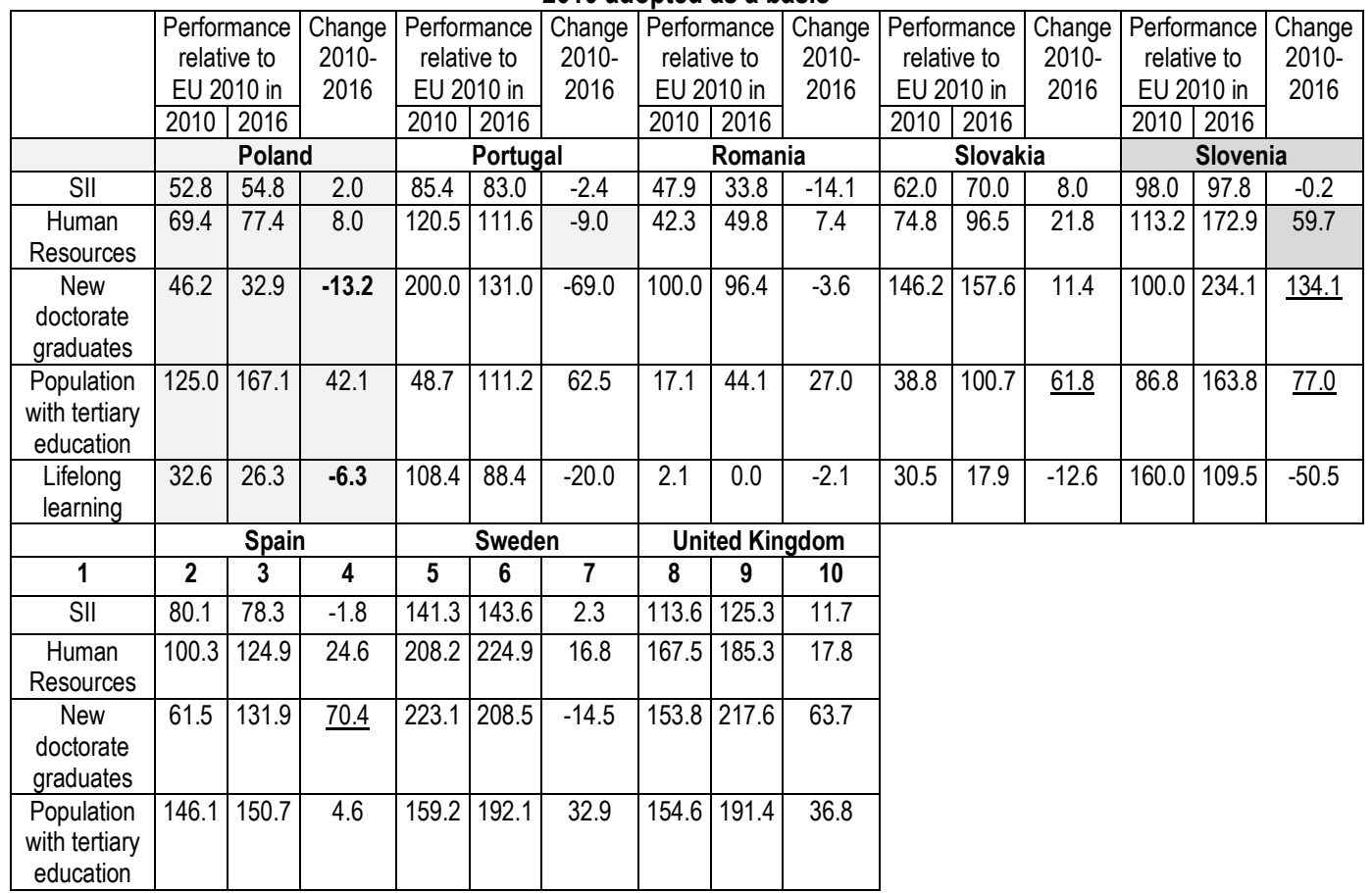




\begin{tabular}{|c|c|c|c|c|c|c|c|c|c|}
\hline $\mathbf{1}$ & $\mathbf{2}$ & $\mathbf{3}$ & $\mathbf{4}$ & $\mathbf{5}$ & $\mathbf{6}$ & $\mathbf{7}$ & $\mathbf{8}$ & $\mathbf{9}$ & $\mathbf{1 0}$ \\
\hline $\begin{array}{l}\text { Lifelong } \\
\text { learning }\end{array}$ & 93.7 & 86.3 & $\underline{-7.4}$ & 247.4 & 283.2 & 35.8 & 198.9 & 138.9 & -60.0 \\
\hline
\end{tabular}

Source: compiled on the basis of European Innovation Scoreboard, 2017.

In the analyzed period Poland observed an increase of $8 \%$. Out of all EU-28 countries, only Romania (7.4\%) and the aforementioned Portugal observed lower increments. In 2016, compared to 2010, in the case of Poland, the value of the «New doctorate graduates (\% population aged 25-34)» indicator decreased significantly by $13.2 \%$. There was also a decline in the value of the «Percentage population aged $25-64$ participating in lifelong learning» indicator by $6.3 \%$. However, improvement was noted in the case of the «Percentage population aged 25-34 having completed tertiary education» indicator - an increase of $42.1 \%$.

Poland's low innovative position against the background of the EU countries was also confirmed by the analysis of the evolution of the Global Innovation Index (GII) 2017.

The Global Innovation Index consists of two sub-indicators: Innovation Output Sub-Index and Innovation Input Sub-Index, where each of them is described by individual «pillars». One of the five pillars of the sub-index of input in innovation (innovation input) is the pillar of Human capital \& research. It consists of the following areas: Education, Tertiary education, Research \& development (R\&D).

Each area is assigned specific indicators. The performed comparative analysis assumes 2011 as the start of the analysis, and not 2010 as was the case in earlier analyses. This results from significant changes in the structure of the GII in years prior to 2011. It also needs to be emphasized, that in the case of the Human capital \& research pillar the main framework of its structure in 2016 compared to 2011 changed partially (slightly) - the number and kind of indicators forming its components changed: Tertiary education (compared to 2016 it lost the following indicators: Tertiary outbound mobility, \%; Gross tertiary outbound enrolment, \%), R\&D (in 2011 - no Quality research institutions indicator) (INSEAD, 2011). The framework of the Human capital \& research pillar in 2016 is presented in Figure 5.

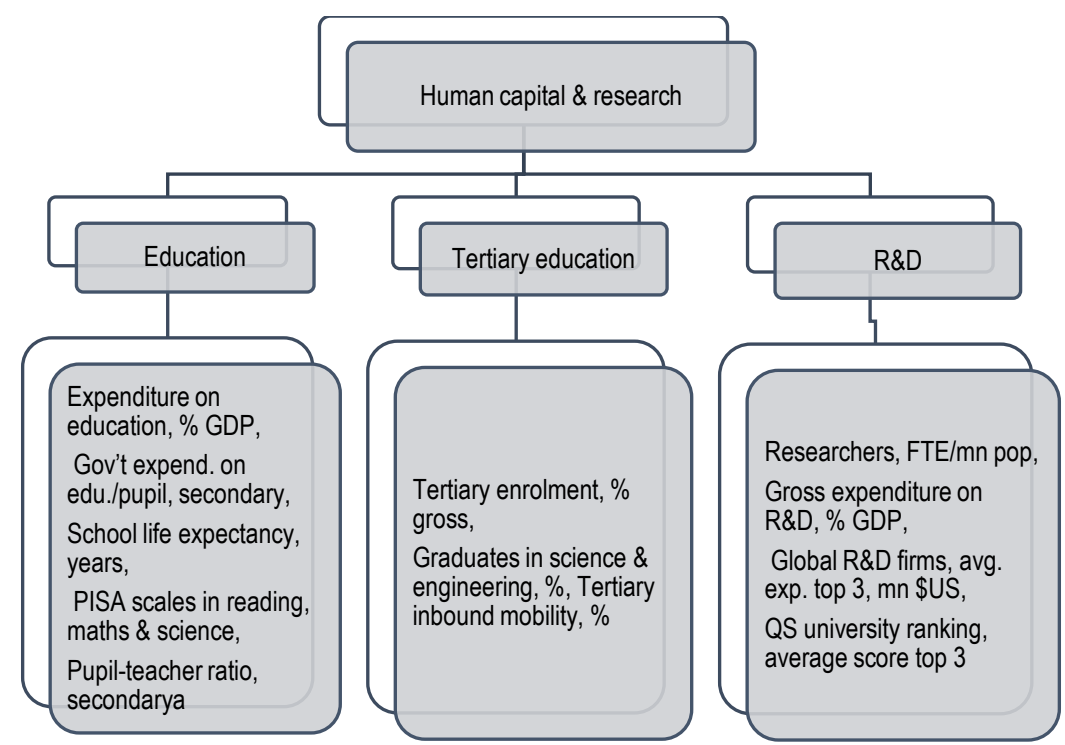

Figure 5. Framework of the Human capital \& research pillar of the Global Innovation Index 2016 Source: compiled on the basis of: (Cornell University et al. 2016). 
In 2016, Poland was ranked $38^{\text {th }}$ out of the 127 countries analyzed. Whereas in the group of the EU28 countries, Poland took $23^{\text {rd }}$ place (behind Bulgaria). The best results among the EU-28 countries were achieved by Sweden, the Netherlands, the United Kingdom, Denmark, Finland, Germany and Ireland countries which in the current ranking were among the 10 most innovative countries in the world.

In 2011, among the EU countries, Poland held the 24th position (on par with Croatia), only ahead of Romania and Greece. The composition of the «leading countries» was very similar to that in 2016 (Table 7).

Table 7. The development of the GII and Human capital \& research indicators (including their component areas) for EU countries in 2011 and 2016

\begin{tabular}{|c|c|c|c|c|c|c|c|c|c|c|}
\hline & Gll & $\begin{array}{l}\text { Human } \\
\text { capital \& } \\
\text { research }\end{array}$ & Education & $\begin{array}{c}\text { Tertiary } \\
\text { education }\end{array}$ & R\&D & GII & $\begin{array}{c}\text { Human } \\
\text { capital \& } \\
\text { research }\end{array}$ & Education & $\begin{array}{c}\text { Tertiary } \\
\text { education }\end{array}$ & R\&D \\
\hline & \multicolumn{5}{|c|}{2011} & \multicolumn{5}{|c|}{2016} \\
\hline EU-28 & 45.2 & 48.7 & 66.8 & 38.9 & 40.3 & 49.7 & 50.1 & 60.4 & 46.9 & 43.0 \\
\hline Sweden & 62.1 & 63.3 & 74.3 & 42.3 & 73.2 & 63.6 & 64.8 & 69.1 & 46.9 & 78.4 \\
\hline Denmark & 57.0 & 60.2 & 79.4 & 37.6 & 63.6 & 58.5 & 65.8 & 70.9 & 50.8 & 75.6 \\
\hline Finland & 57.5 & 66.5 & 76.9 & 49.0 & 73.5 & 59.9 & 68.1 & 72.3 & 57.2 & 74.9 \\
\hline Netherlands & 56.3 & 47.6 & 70.6 & 28.4 & 43.9 & 58.3 & 55.3 & 60.4 & 40.0 & 65.5 \\
\hline United Kingdom & 56.0 & 56.1 & 66.8 & 42.8 & 56.6 & 61.9 & 62.6 & 58.4 & 60.1 & 69.4 \\
\hline Germany & 54.9 & 57.5 & 72.5 & 42.4 & 57.8 & 57.9 & 58.9 & 56.9 & 46.0 & 74.0 \\
\hline Austria & 50.7 & 58.7 & 69.9 & 48.9 & 57.4 & 52.6 & 60.8 & 58.3 & 65.7 & 58.3 \\
\hline Luxembourg & 52.7 & 56.6 & 61.1 & 63.9 & 44.7 & 57.1 & 43.3 & 51.9 & 44.0 & 33.9 \\
\hline Belgium & 49.0 & 52.9 & 73.9 & 33.2 & 51.7 & 52.0 & 58.9 & 72.1 & 44.3 & 60.3 \\
\hline Ireland & 54.1 & 57.8 & 79.3 & 49.3 & 44.7 & 59.0 & 54.0 & 60.7 & 47.9 & 53.4 \\
\hline France & 49.3 & 53.0 & 69.3 & 41.5 & 48.2 & 54.0 & 58.9 & 57.7 & 51.1 & 67.9 \\
\hline Slovenia & 45.1 & 51.3 & 74.3 & 36.8 & 42.9 & 46.0 & 50.4 & 63.0 & 46.7 & 41.3 \\
\hline Czech Republic & 47.3 & 49.9 & 66.2 & 40.0 & 43.5 & 49.4 & 48.3 & 54.8 & 49.3 & 40.6 \\
\hline Portugal & 42.4 & 52.5 & 73.7 & 40.8 & 43.0 & 46.4 & 48.7 & 60.3 & 45.5 & 40.3 \\
\hline Estonia & 49.2 & 50.5 & 69.8 & 39.1 & 42.6 & 51.7 & 81.2 & 74.9 & 87.0 & 81.6 \\
\hline Lithuania & 38.5 & 47.0 & 67.7 & 39.9 & 33.4 & 41.8 & 49.1 & 86.3 & 40.7 & 20.2 \\
\hline Spain & 43.8 & 48.2 & 67.3 & 38.9 & 38.4 & 49.2 & 49.7 & 56.4 & 44.7 & 48.2 \\
\hline Malta & 0 & 0 & 0 & 0 & 0 & 50.4 & 41.1 & 66.3 & 35.6 & 21.2 \\
\hline Italy & 40.7 & 44.5 & 69.4 & 35.1 & 29.1 & 47.2 & 46.5 & 52.3 & 39.1 & 48.0 \\
\hline Cyprus & 46.5 & 48.6 & 69.6 & 50.5 & 25.8 & 46.3 & 38.7 & 63.1 & 48.4 & 4.8 \\
\hline Slovakia & 39.0 & 42.8 & 61.3 & 42.4 & 24.8 & 41.7 & 32.8 & 47.3 & 38.0 & 13.2 \\
\hline Greece & 34.2 & 47.4 & 66.3 & 51.7 & 24.1 & 39.8 & 55.3 & 76.8 & 58.7 & 30.3 \\
\hline Hungary & 48.1 & 45.7 & 70.0 & 28.9 & 38.2 & 44.7 & 41.2 & 52.1 & 35.8 & 35.9 \\
\hline Latvia & 39.8 & 42.8 & 69.7 & 30.5 & 28.3 & 44.3 & 31.4 & 48.3 & 36.5 & 9.5 \\
\hline Poland & 38.0 & 42.4 & 68.8 & 30.7 & 27.6 & 40.2 & 39.2 & 57.1 & 34.0 & 27.7 \\
\hline Croatia & 38.0 & 43.5 & 64.5 & 36.8 & 29.1 & 38.3 & 35.7 & 59.1 & 37.6 & 10.4 \\
\hline Bulgaria & 38.4 & 39.2 & 59.8 & 36.3 & 21.5 & 41.4 & 32.1 & 44.7 & 40.2 & 11.5 \\
\hline Romania & 36.8 & 36.8 & 58.6 & 31.3 & 20.4 & 37.9 & 30.2 & 40.5 & 41.1 & 8.9 \\
\hline
\end{tabular}

Source: compiled on the basis of: (INSEAD, 2011; Cornell University et al. 2016).

When grouping countries using the criterion adopted by the EU to differentiate four groups of countries diversified in terms of innovation for the SII it is noticeable that the countries' belonging with individual groups in the framework of the development of the GII in the analyzed years, that is 2011 and 2016, was not subject to significant changes (Tables 8a, 8b, 8c).

In the case of the GII in 2011 and 2016 Poland was classified in Group II. What is interesting, none of the EU countries were classified in the group showing a very low level of innovation (Group I). Table 8 lists countries for which values of the GII, Human capital \& research, Education, Tertiary education, R\&D (indicators) fall within the range according to the adopted classification criterion. 
Table 8a. Grouping EU countries ( Group IV) according to the value of the GII and Human capital \& research indicators in 2011 and 2016

\begin{tabular}{|c|c|c|c|c|c|c|c|c|c|c|}
\hline \multirow[t]{3}{*}{ Group } & \multicolumn{10}{|c|}{ States belonging in the group } \\
\hline & \multicolumn{2}{|c|}{ GII } & \multicolumn{2}{|c|}{$\begin{array}{l}\text { Human capital \& } \\
\text { research }\end{array}$} & \multicolumn{2}{|c|}{ Education } & \multicolumn{2}{|c|}{ Tertiary education } & \multicolumn{2}{|c|}{ R\&D } \\
\hline & 2011 & 2016 & 2011 & 2016 & 2011 & 2016 & 2011 & 2016 & 2011 & 2016 \\
\hline IV & $\begin{array}{c}\text { Netherlands } \\
\text { the UK } \\
\text { Germany } \\
\text { Denmark } \\
\text { Sweden } \\
\text { Finland }\end{array}$ & $\begin{array}{c}\text { Sweden } \\
\text { Finland } \\
\text { United } \\
\text { Kingdom }\end{array}$ & \begin{tabular}{|c|} 
Austria \\
Denmark \\
Sweden \\
Finland
\end{tabular} & $\begin{array}{c}\text { Denmark } \\
\text { Austria } \\
\text { Estonia } \\
\text { Sweden } \\
\text { Finland } \\
\text { the UK }\end{array}$ & & $\begin{array}{c}\text { Lithuania } \\
\text { Greece } \\
\text { Estonia }\end{array}$ & $\begin{array}{c}\text { Greece } \\
\text { Cyprus } \\
\text { Luxembourg } \\
\text { Ireland } \\
\text { Austria } \\
\text { Finland }\end{array}$ & $\begin{array}{l}\text { Austria } \\
\text { Finland } \\
\text { the UK } \\
\text { Greece } \\
\text { Estonia }\end{array}$ & 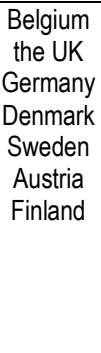 & $\begin{array}{l}\text { Netherlands } \\
\text { Germany } \\
\text { Belgium } \\
\text { Ireland } \\
\text { France } \\
\text { Denmark } \\
\text { Sweden } \\
\text { Austria } \\
\text { Finland } \\
\text { the UK } \\
\text { Estonia }\end{array}$ \\
\hline
\end{tabular}

Source: author's own compilation.

Table 8b. Grouping EU countries (Group III) according to the value of the GII and Human capital \& research indicators in 2011 and 2016

\begin{tabular}{|c|c|c|c|c|c|c|c|c|c|c|}
\hline \multirow{3}{*}{ Group } & \multicolumn{10}{|c|}{ States belonging in the group } \\
\hline & \multicolumn{2}{|c|}{ GII } & \multicolumn{2}{|c|}{$\begin{array}{c}\text { Human capital \& } \\
\text { research }\end{array}$} & \multicolumn{2}{|c|}{ Education } & \multicolumn{2}{|c|}{ Tertiary education } & \multicolumn{2}{|l|}{ R\&D } \\
\hline & 2011 & 2016 & 2011 & 2016 & 2011 & 2016 & 2011 & 2016 & 2011 & 2016 \\
\hline III & \begin{tabular}{|c||} 
Italy \\
Hungary \\
Spain \\
Czech \\
Republic \\
Cyprus \\
Estonia \\
Slovenia \\
Portugal \\
France \\
Belgium \\
Luxembourg \\
Austria \\
Ireland
\end{tabular} & \begin{tabular}{|l} 
Luxembourg \\
Portugal \\
Malta \\
Italy \\
Cyprus \\
Slovenia \\
Czech \\
Republic \\
Spain \\
Denmark \\
Netherlands \\
Germany \\
Austria \\
Belgium \\
Ireland \\
France \\
Estonia
\end{tabular} & \begin{tabular}{|c|} 
Greece \\
Lithuania \\
Italy \\
Hungary \\
Spain \\
Czech \\
Republic \\
Cyprus \\
Estonia \\
Slovenia \\
Portugal \\
France \\
Belgium \\
Luxembourg \\
Ireland \\
Netherlands \\
the UK \\
Germany
\end{tabular} & \begin{tabular}{|l} 
Lithuania \\
Greece \\
Portugal \\
Italy \\
Slovenia \\
Czech \\
Republic \\
Spain \\
Netherlands \\
Germany \\
Belgium \\
Ireland \\
France \\
\end{tabular} & \begin{tabular}{|c|} 
Slovakia \\
Poland \\
Croatia \\
Latvia \\
Greece \\
Lithuania \\
Italy \\
Hungary \\
Spain \\
Czech \\
Republic \\
Cyprus \\
Estonia \\
Slovenia \\
Portugal \\
France \\
Belgium \\
Luxembourg \\
Ireland \\
Netherlands \\
the UK \\
Germany \\
Austria \\
Denmark \\
Sweden \\
Finland \\
\end{tabular} & \begin{tabular}{|l|} 
Poland \\
Croatia \\
Malta \\
Cyprus \\
Portugal \\
Slovenia \\
Czech \\
Republic \\
Spain \\
Netherlands \\
Germany \\
Belgium \\
Ireland \\
France \\
Denmark \\
Austria \\
Sweden \\
Finland \\
the UK \\
\end{tabular} & $\begin{array}{c}\text { Bulgaria } \\
\text { Slovakia } \\
\text { Croatia } \\
\text { Lithuania } \\
\text { Italy } \\
\text { Spain } \\
\text { Czech } \\
\text { Republic } \\
\text { Estonia } \\
\text { Slovenia } \\
\text { Portugal } \\
\text { France } \\
\text { the UK } \\
\text { Germany } \\
\text { Denmark } \\
\text { Sweden }\end{array}$ & \begin{tabular}{|c} 
Luxembourg \\
Cyprus \\
Portugal \\
Slovenia \\
Czech \\
Republic \\
Spain \\
Germany \\
Belgium \\
Ireland \\
France \\
Denmark \\
Sweden
\end{tabular} & \begin{tabular}{|c|} 
Hungary \\
Netherlands \\
Spain \\
Czech \\
Republic \\
Estonia \\
Slovenia \\
Portugal \\
France \\
Luxembourg \\
Ireland
\end{tabular} & $\begin{array}{c}\text { Italy } \\
\text { Portugal } \\
\text { Slovenia } \\
\text { Czech } \\
\text { Republic } \\
\text { Spain }\end{array}$ \\
\hline
\end{tabular}

Source: author's own compilation. 
Table 8c. Grouping EU countries (Group II and I) according to the value of the GII and Human capital \& research indicators in 2011 and 2016

\begin{tabular}{|c|c|c|c|c|c|c|c|c|c|c|}
\hline \multirow[t]{3}{*}{ Group } & \multicolumn{10}{|c|}{ States belonging in the group } \\
\hline & \multicolumn{2}{|c|}{ GII } & \multicolumn{2}{|c|}{$\begin{array}{c}\text { Human capital \& } \\
\text { research }\end{array}$} & \multicolumn{2}{|c|}{ Education } & \multicolumn{2}{|c|}{ Tertiary education } & \multicolumn{2}{|c|}{ R\&D } \\
\hline & 2011 & 2016 & 2011 & 2016 & 2011 & 2016 & 2011 & 2016 & 2011 & 2016 \\
\hline II & $\begin{array}{c}\text { Romania } \\
\text { Bulgaria } \\
\text { Slovakia } \\
\text { Poland } \\
\text { Croatia } \\
\text { Latvia } \\
\text { Greece } \\
\text { Lithuania }\end{array}$ & $\begin{array}{c}\text { Slovakia } \\
\text { Latvia } \\
\text { Poland } \\
\text { Croatia } \\
\text { Bulgaria } \\
\text { Romania } \\
\text { Hungary } \\
\text { Lithuania } \\
\text { Greece }\end{array}$ & $\begin{array}{c}\text { Romania } \\
\text { Bulgaria } \\
\text { Slovakia } \\
\text { Poland } \\
\text { Croatia } \\
\text { Latvia }\end{array}$ & 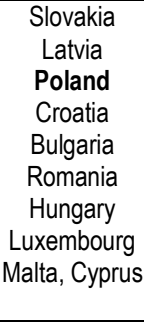 & $\begin{array}{c}\text { Romania } \\
\text { Bulgaria }\end{array}$ & $\begin{array}{c}\text { Slovakia } \\
\text { Latvia } \\
\text { Bulgaria } \\
\text { Romania } \\
\text { Hungary } \\
\text { Luxembourg } \\
\text { Italy }\end{array}$ & $\begin{array}{c}\text { Romania } \\
\text { Poland } \\
\text { Latvia } \\
\text { Hungary } \\
\text { Belgium } \\
\text { Netherlands }\end{array}$ & \begin{tabular}{|c|} 
Slovakia \\
Latvia \\
Bulgaria \\
Romania \\
Hungary \\
Italy \\
Poland \\
Croatia, Malta \\
Netherlands \\
Lithuania \\
\end{tabular} & $\begin{array}{c}\text { Romania } \\
\text { Poland } \\
\text { Latvia } \\
\text { Bulgaria } \\
\text { Slovakia } \\
\text { Croatia } \\
\text { Lithuania } \\
\text { Italy } \\
\text { Greece } \\
\text { Cyprus } \\
\end{array}$ & $\begin{array}{c}\text { Hungary } \\
\text { Poland } \\
\text { Luxembourg } \\
\text { Greece }\end{array}$ \\
\hline I & & & & & & & & & & $\begin{array}{c}\text { Slovakia } \\
\text { Latvia } \\
\text { Bulgaria } \\
\text { Romania } \\
\text { Croatia, Malta } \\
\text { Lithuania } \\
\text { Cyprus } \\
\end{array}$ \\
\hline
\end{tabular}

Source: author's own compilation.

The information contained in Table 8 shows that the values of the Human capital \& research pillar (indicator) for Poland in 2011 and 2016 classified it to Group 2. Also in the case of the values of two areas forming Human capital \& research, that is Tertiary education and R\&D, was Poland classified in Group 2. Only the values achieved by Poland for the Education area reached a higher, third level.

For the remaining countries, comparing 2011 and 2016, the following countries achieved a lower position for the development of the GII, thus featured in a group with a lower level of innovation: Denmark, Germany, the Netherlands and Hungary. The rest of the countries stayed in the same group in the investigated years.

Data for the Human capital \& research pillar shows that in 2016, compared to 2011, the following countries moved up a level: Estonia and the United Kingdom, whereas Cyprus, Hungary and Luxembourg moved down a level.

In the development of the Tertiary education area (indicator) the following countries were at a lower level in 2016 compared to 2011: Bulgaria, Croatia, Cyprus, Ireland, Italy, Lithuania, Luxembourg and Slovakia. Whereas Belgium, Estonia and the United Kingdom advanced to a higher level.

An increase in the value (indicator) of the «Education» area allowed the following countries to move up a level in 2016 compared to the one they were at in 2011: Estonia, Greece, and Lithuania. Hungary, Italy, Latvia, Luxembourg and Slovakia had to move down a level.

In turn, the values for the R\&D area (indicator) achieved in 2016 by Bulgaria, Croatia, Cyprus, Hungary, Latvia, Lithuania, Luxembourg, Romania and Slovakia placed them on a level lower than in 2011. Whereas Estonia, France, Ireland, Italy and the Netherland were classified in a higher level group in 2016.

Human Resources in Science and Technology play a particular role in creating and absorbing innovation. Often differences in the rate of economic growth and in the level of innovation between individual countries can be explained by Human Resources in Science and Technology.

International methodological recommendations regarding the measurement of Human Resources in Science and Technology as well as methods of analysis of the structure and changes occurring in it were included in the Canberra Manual. HRST are formed with people currently engaged in or potentially able 
to perform work related to the creation, development, promotion and application of scientific and technical knowledge. The indicator understood in this way covers two groups. The first includes people who have formal qualifications, that is third-level education in the field of science and technology (S\&T). The second consists of people who do not have formal education but work in professions of science and technology, where such education is usually required.

In 2016, in the European Union (EU-28), Human Resources in Science and Technology accounted for $46 \%$ of active population (Fig. 6 ).

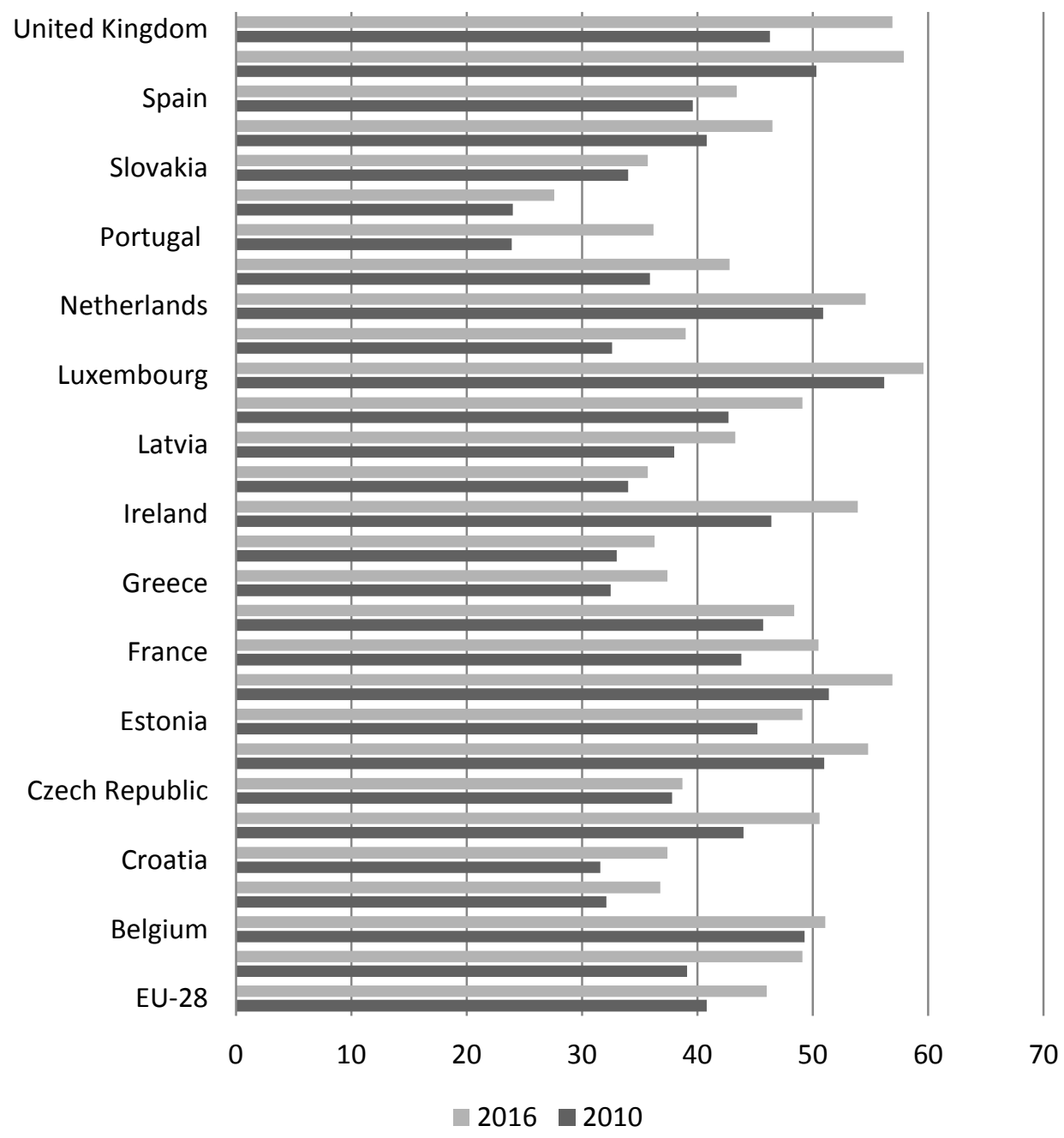

Figure 6. The development of the HRST indicator in the European Union in 2010 and 2016 (\% of Source: compiled on the basis of Eurostat date. active population)

In comparison with the data from 2010, there was a clear increase in the share of human resources in science and technology in the economically active population (increase by $5.2 \mathrm{pp}$ ). In individual countries, 
the situation in terms of HRST's share was very diverse. In 2010, the highest share of HRST in economically active people was observed in Luxembourg (56.2\%), Finland (51.4\%), and the lowest in Romania (24\%) and Portugal (23.9\%). In turn, in 2016, the highest share was seen in Luxembourg (59.6\%), Sweden (57.9\%), Finland and the United Kingdom (56.9\% each), and the lowest in Romania (27.6\%). Poland ranked below the EU-28 average at the $18^{\text {th }}$ position (Poland $-42.8 \%$, EU-28 - 46.0\%).

The following terms operate within HRST:

1. HRSTE (Human Resources in Science and Technology - Education) - includes people whose formal level of education gives basis to undertake work in occupations predisposed to the area of the R\&D sector.

2. HRSTO (Human Resources in Science and Technology - Occupation) - includes people employed in R\&D professions according to the ISCO classification.

3. HRSTC (Human Resources in Science and Technology - Core) - includes people who have completed a tertiary level education exactly in the field of technical sciences and are working in occupations in the R\&D area.

Table 9. The development of indicators, (the development of values) of HRSTE, HRSTO and HRSTC for the EU-28 countries in 2010 and 2016 (\% of active population)

\begin{tabular}{|c|c|c|c|c|c|c|}
\hline \multirow[t]{2}{*}{ Countries } & \multicolumn{2}{|c|}{ HRSTE } & \multicolumn{2}{|c|}{ HRSTO } & \multicolumn{2}{|c|}{ HRSTC } \\
\hline & 2010 & 2016 & 2010 & 2016 & 2010 & 2016 \\
\hline UE-28 & 27.7 & 32.6 & 28.1 & 32.1 & 17.2 & 20.7 \\
\hline Austria & 19.1 & 33.1 & 29.9 & 34.0 & 12.3 & 19.8 \\
\hline Belgium & 38.9 & 42.2 & 31.3 & 34.6 & 22.8 & 27.3 \\
\hline Bulgaria & 25.8 & 31.0 & 20.7 & 24.4 & 15.7 & 19.4 \\
\hline Croatia & 17.5 & 23.5 & 23.5 & 27.1 & 15.3 & 18.4 \\
\hline Cyprus & 37.8 & 44.7 & 25.6 & 26.9 & 20.7 & 22.3 \\
\hline Czech Republic & 17.5 & 23.5 & 32.7 & 31.2 & 13.5 & 17.0 \\
\hline Denmark & 30.2 & 33.9 & 37.6 & 39.7 & 22.8 & 25.5 \\
\hline Estonia & 35.5 & 38.9 & 26.2 & 30.0 & 18.2 & 21.5 \\
\hline Finland & 37.3 & 41.7 & 32.8 & 39.1 & 23.3 & 29.0 \\
\hline France & 31.6 & 37.7 & 30.0 & 34.2 & 19.3 & 23.0 \\
\hline Germany & 26.6 & 28.3 & 34.6 & 38.2 & 17.7 & 20.1 \\
\hline Greece & 26.8 & 32.7 & 21.1 & 21.0 & 16.8 & 17.4 \\
\hline Hungary & 22.6 & 25.3 & 25.0 & 28.1 & 15.5 & 18.3 \\
\hline Ireland & 38.7 & 43.7 & 22.8 & 30.1 & 18.6 & 23.7 \\
\hline Italy & 17.1 & 20.2 & 27.7 & 28.4 & 12.3 & 14.2 \\
\hline Latvia & 28.0 & 35.0 & 24.6 & 29.0 & 16.0 & 21.7 \\
\hline Lithuania & 35.5 & 42.0 & 26.6 & 30.4 & 20.5 & 24.8 \\
\hline Luxembourg & 37.2 & 40.6 & 48.2 & 50.9 & 30.9 & 34.3 \\
\hline Malta & 19.9 & 24.7 & 25.6 & 29.9 & 14.2 & 16.7 \\
\hline Netherlands & 31.4 & 34.8 & 36.1 & 39.0 & 21.3 & 24.7 \\
\hline Poland & 25.9 & 32.6 & 25.3 & 29.6 & 16.9 & 21.1 \\
\hline Portugal & 16.3 & 25.5 & 17.7 & 26.8 & 11.4 & 17.8 \\
\hline Romania & 15.4 & 20.0 & 18.2 & 20.0 & 11.5 & 14.2 \\
\hline Slovakia & 18.3 & 22.6 & 26.9 & 24.4 & 12.8 & 14.0 \\
\hline Slovenia & 25.5 & 33.9 & 29.9 & 32.1 & 17.1 & 21.5 \\
\hline Spain & 33.5 & 38.3 & 21.9 & 23.3 & 17.5 & 19.3 \\
\hline Sweden & 32.3 & 39.4 & 37.4 & 42.8 & 23.7 & 28.5 \\
\hline United Kingdom & 35.5 & 42.3 & 26.0 & 35.8 & 18.6 & 24.7 \\
\hline
\end{tabular}

Source: compiled on the basis of Eurostat date (www.ec.europa.eu/eurostat/).

The analysis of data contained in Table 9 shows that the values of all three indicators for Poland in 2010 were unsatisfactory, lower than the average values for the (current) EU-28. It should be emphasized, 
however, that in 2016 all three indicators obtained higher values compared to values from 2010 . In the case of the HRSTE indicator, its value for Poland equaled the EU average (32.6\%), HRSTC for Poland was higher than the average for the EU-28 (Poland: 21.1\%, EU-28: 20.7\%). Only in the case of HRSTO, the value of the indicator for Poland was slightly lower than the EU-28 average.

In 2016, in the general classification of EU-28 countries in terms of the value of the HRSTE indicator, Poland was placed on the $18^{\text {th }}$ position, HRSTO $-17^{\text {th }}$ position, HRSTC $-15^{\text {th }}$ position.

The value of indicators for Poland in 2016 in relation to 2010 increased by $25.7 \%, 17.0 \%$ and $24.9 \%$, respectively. This means that the number of people whose formal level of education allowed them to take up employment in occupations within the R\&D field increased to the greatest extent.

Among all the analyzed countries, in the context of the discussed indicators, Denmark, Luxembourg, Finland and Sweden performed by far the best, while Romania did the worst. It is worth emphasizing that in the case of the percentage of people employed in R\&D occupations, predominance of countries belonging to the so-called Western European countries - the so-called old European Union, its northern countries, was observed.

When grouping the countries using the criterion adopted by the EU to differentiate four groups of countries diversified in terms of innovation for the SII it is noticeable that the countries' belonging with individual groups in the framework of the development of the HRST indicator and its components, that is HRSTE, HRSTO and HRSTC, in the analyzed years, that is 2010 and 2016, was not subject to significant changes (Tables 10a, 10b).

Table 10a. The development of the HRST indicator and its components, that is HRSTE, HRSTO and HRSTC, for the EU countries in 2010 and 2016 (Groups IV, III)

\begin{tabular}{|c|c|c|c|c|c|c|c|c|}
\hline \multirow[t]{3}{*}{ Group } & \multicolumn{8}{|c|}{ States belonging in the group } \\
\hline & \multicolumn{2}{|c|}{ HRST } & \multicolumn{2}{|c|}{ HRSTE } & \multicolumn{2}{|c|}{ HRSTO } & \multicolumn{2}{|c|}{ HRSTC } \\
\hline & 2010 & 2016 & 2010 & 2016 & 2010 & 2016 & 2010 & 2016 \\
\hline IV & $\begin{array}{c}\text { Belgium } \\
\text { Denmark } \\
\text { Finland } \\
\text { Netherlands } \\
\text { Sweden }\end{array}$ & $\begin{array}{l}\text { the UK } \\
\text { Finland } \\
\text { Sweden }\end{array}$ & $\begin{array}{l}\text { Cyprus } \\
\text { Estonia } \\
\text { Ireland } \\
\text { Lithuania } \\
\text { Spain } \\
\text { Belgium } \\
\text { the UK } \\
\text { Finland }\end{array}$ & $\begin{array}{l}\text { Sweden } \\
\text { Cyprus } \\
\text { Ireland } \\
\text { Lithuania } \\
\text { Belgium } \\
\text { the UK } \\
\text { Finland }\end{array}$ & $\begin{array}{l}\text { Germany } \\
\text { Denmark } \\
\text { Netherlands } \\
\text { Sweden }\end{array}$ & $\begin{array}{c}\text { Finland } \\
\text { Denmark } \\
\text { Netherlands } \\
\text { Sweden }\end{array}$ & $\begin{array}{c}\text { Cyprus } \\
\text { Belgium } \\
\text { Finland } \\
\text { Denmark } \\
\text { Netherlands } \\
\text { Sweden }\end{array}$ & $\begin{array}{l}\text { Belgium } \\
\text { Finland } \\
\text { Denmark } \\
\text { Sweden }\end{array}$ \\
\hline III & $\begin{array}{c}\text { Austria } \\
\text { Cyprus } \\
\text { Czech } \\
\text { Republic } \\
\text { Estonia } \\
\text { France } \\
\text { Germany } \\
\text { Ireland } \\
\text { Latvia } \\
\text { Lithuania } \\
\text { Slovenia } \\
\text { Spain } \\
\text { the UK }\end{array}$ & $\begin{array}{l}\text { Poland } \\
\text { Austria } \\
\text { Cyprus } \\
\text { Estonia } \\
\text { France } \\
\text { Germany } \\
\text { Ireland } \\
\text { Latvia } \\
\text { Lithuania } \\
\text { Slovenia } \\
\text { Spain } \\
\text { Belgium } \\
\text { Denmark } \\
\text { Netherlands }\end{array}$ & $\begin{array}{c}\text { Bulgaria } \\
\text { Greece } \\
\text { Poland } \\
\text { France } \\
\text { Germany } \\
\text { Latvia } \\
\text { Slovenia } \\
\text { Denmark } \\
\text { Netherlands } \\
\text { Sweden }\end{array}$ & $\begin{array}{c}\text { Austria } \\
\text { Bulgaria } \\
\text { Greece } \\
\text { Poland } \\
\text { France } \\
\text { Latvia } \\
\text { Slovenia } \\
\text { Denmark } \\
\text { Netherlands } \\
\text { Estonia } \\
\text { Spain }\end{array}$ & $\begin{array}{c}\text { Italy } \\
\text { Malta } \\
\text { Slovakia } \\
\text { Czech Republic } \\
\text { Austria } \\
\text { Poland } \\
\text { France } \\
\text { Slovenia } \\
\text { Estonia } \\
\text { Cyprus } \\
\text { Lithuania } \\
\text { Belgium } \\
\text { the UK } \\
\text { Finland }\end{array}$ & $\begin{array}{l}\text { Latvia } \\
\text { Ireland } \\
\text { Malta } \\
\text { Czech } \\
\text { Republic } \\
\text { Austria } \\
\text { Poland } \\
\text { France } \\
\text { Slovenia } \\
\text { Estonia } \\
\text { Lithuania } \\
\text { Belgium } \\
\text { the UK } \\
\text { Germany }\end{array}$ & $\begin{array}{l}\text { Hungary } \\
\text { Bulgaria } \\
\text { Greece } \\
\text { Spain } \\
\text { Latvia } \\
\text { Ireland } \\
\text { Poland } \\
\text { France } \\
\text { Slovenia } \\
\text { Estonia } \\
\text { Lithuania } \\
\text { the UK } \\
\text { Germany }\end{array}$ & $\begin{array}{l}\text { Austria } \\
\text { Bulgaria } \\
\text { Spain } \\
\text { Latvia } \\
\text { Ireland } \\
\text { Poland } \\
\text { France } \\
\text { Slovenia } \\
\text { Estonia } \\
\text { Lithuania } \\
\text { the UK } \\
\text { Germany } \\
\text { Cyprus } \\
\text { Netherlands }\end{array}$ \\
\hline
\end{tabular}

Source: author's own compilation. 
Table 10b. The development of the HRST indicator and its components, that is HRSTE, HRSTO and HRSTC, for the EU countries in 2010 and 2016 (Groups II, I)

\begin{tabular}{|c|c|c|c|c|c|c|c|c|}
\hline \multirow[t]{3}{*}{ Group } & \multicolumn{8}{|c|}{ States belonging in the group } \\
\hline & \multicolumn{2}{|c|}{ HRST } & \multicolumn{2}{|c|}{ HRSTE } & \multicolumn{2}{|c|}{ HRSTO } & \multicolumn{2}{|c|}{ HRSTC } \\
\hline & 2010 & 2016 & 2010 & 2016 & 2010 & 2016 & 2010 & 2016 \\
\hline \multirow[t]{9}{*}{ II } & Bulgaria & Bulgaria & Croatia & Croatia & Croatia & Croatia & Croatia & Croatia \\
\hline & Croatia & Croatia & Hungary & Hungary & Hungary & Hungary & Portugal & Portugal \\
\hline & Greece & Greece & Italy & Italy & Portugal & Portugal & Romania & Romania \\
\hline & Hungary & Hungary & Malta & Malta & Romania & Romania & Italy & Italy \\
\hline & Italy & Italy & Portugal & Portugal & Bulgaria & Bulgaria & Slovakia & Slovakia \\
\hline & Malta & Malta & Romania & Romania & Greece & Greece & Malta & Malta \\
\hline & Poland & Portugal & Slovakia & Slovakia & Latvia & Spain & Czech & Czech Republic \\
\hline & Portugal & Romania & Czech Republic & Czech Republic & Spain & Italy & Republic & Hungary \\
\hline & $\begin{array}{l}\text { Romania } \\
\text { Slovakia }\end{array}$ & $\begin{array}{c}\text { Slovakia } \\
\text { Czech Republic }\end{array}$ & Austria & Germany & Ireland & Slovakia & Austria & Greece \\
\hline I & & & & & & & & \\
\hline
\end{tabular}

Source: author's own compilation.

An increase of the HRST indicator in 2016 compared to 2010 in Poland contributed to its advancement to a higher level (a move from Group II to Group III). For HRSTE, HRSTO and HRSTC Poland was classified in the same group (III) in both analyzed years.

For the remaining countries, comparing 2010 and 2016, the following countries achieved a lower position for the development of the HRST indicator, thus appeared in a lower level group: Belgium, the Czech Republic, Denmark and the Netherlands. Only the United Kingdom (apart from aforementioned Poland) advanced to a higher level.

Data for HRST shows that in 2016 compared to 2010 the following countries advanced to a group higher by one level: Austria and Sweden, whereas Estonia and Germany moved down a level.

In the case of the development of the HRST values, Cyprus and Slovakia were at a higher level in 2016 compared to 2010. In turn, Finland, Ireland and Latvia advanced by one level.

The decrease in HRST values resulted in Cyprus, Greece, Hungary and the Netherlands being classified at one level lower in 2016 compared to 2010. Only Austria advanced in 2016 compared to 2010 - it moved to a group one level higher.

Conclusion. Innovation is what certainly to a large extent affects the dynamics of economic development (cf. De Bruijn, Lagendijk 2005). The future belongs to those countries that care for having a high level of innovation. Thanks to this, they will strengthen their (already significant in the case of most of them) competitive position on the market.

The 21 st century has been called the conceptual age in which the quality of thoughts, ideas and concepts is taken as the basis for competition, an age in which there are - so far unseen - opportunities for developing talents and originative and creative functioning.

Therefore, it is worth caring for what is of fundamental importance to innovative activity, namely human resources, their capital, of course also bearing in mind other factors affecting its level.

The study focuses in particular on the assessment of the level of human capital - a fundamental element determining the development of innovation. The analyses involved the countries of the European Union, focusing mainly on Poland. The assessment employed innovation indices (SII, GII), also taking into account their human resources-related components. Additionally, the HRST indicator along with its components was used in the context of human resources.

The conducted analyses showed that:

1. European Union Member States feature great diversification in terms of values of innovation indices (both the SII and the GII) as well as in terms of values of human capital indicators in the context of innovation. 
2. The disproportions between individual countries of the European Union in terms of the value of innovation indices are great enough to substantiate a segmentation singling out four essential groups in the area of innovation, i.e. from countries with very low innovation - Group 1, to those most innovative Group 4.

3. Most EU countries both in 2010 and in 2016 were classified in the same groups defining the level of innovation as well as the level of human capital in the context of innovation.

4. Groups of European Union Member States with similar levels of innovation focus approximately around the following geographical directions: northern (highest level of innovation) and eastern (lowest level of innovation).

5. The countries of Northern Europe have maintained stable positions of leaders in terms of innovation for years. This situation is the subject matter of the analyses attempting to establish the reasons for such an outcome. A hypothesis, among others, is being put forward according to which the reason for this has its base in cultural conditions shaped by a difficult climate forcing these countries to a constant struggle for existence and to find ways to survive. Certainly population factors can be excluded as the population potential of Scandinavian countries is approximately ten or even fifteen times smaller than that of Western European countries.

6. When assessing the level of human capital in the innovation context the leaders also mainly include the countries of Northern Europe.

7. Poland's economy features a low level of innovation compared to other EU countries (also the countries of the Central and Eastern Europe block), regardless of the applied indicators. It can thus be assumed that the low level of innovation is a structural characteristic of Polish economy. Changing this situation will be most likely possible only as a result of long-lasting reforms.

8. Polish economy features a low level of human resources indicators in the context of innovation, both in comparison to EU leaders in this field as well as to EU countries with a similar level of economic development.

9. The values of indicators achieved by Poland in terms of innovation, as well as human capital in the context of innovation, are getting higher every year. This trend also concerns other EU countries. Unfortunately, the dynamics of changes in the discussed areas in not too profound in the case of Poland, which translated into its unchanged classification to the same distinguished groups in the analyzed years (usually Group 2).

10. Economies with an above average level of share of human resources in science and technology in economically active people show positively better indicators in terms of innovation. Countries with a low level of innovation, including Poland, must take measures that will boost the construction of innovation potential in the form of human resources in science and technology. Without an adequate quantity and quality of human resources in science and technology, it is impossible to build an innovative, modern economy. It is optimistic that the values of HRSTE, HRSTO, HRSTC indicators for Poland in 2016 in relation to 2010 increased. This means that the number of people whose formal level of education allowed them to take up jobs in occupations in the R\&D area increased the most. However, against the background of other EU-28 countries it is not a significant increase.

11. Wanting to matter on the international arena, Poland must start investing in investment activities. The first step that needs to be taken is to increase (and to increase successively) the level of R\&D spending in GDP and to invest more in the education sector - mainly third level education.

The barriers in terms of possibility to make comparisons in terms of the discussed subject matter can certainly include three basic issues, namely: variability of the structure of individual indices in time, lack of complete data for all countries in the analyzed period as well as an up-to-date status of data (waiting time for data for the current year). 


\section{E. Mazur-Wierzbicka. Human Resources as Fundamental Element Determining the Development of Innovation}

\section{References}

Ang, J.B., Madsen, J.B., Rabiul Islam, M. (2011), The effects of human capital composition on technological convergence, Journal of Macroeconomics, 33(3): 465-476.

Baneliene, R. (2013), Evaluation of the efficiency of economic policy under the Europe-2020 strategy in small European Union countries, Ekonomika, 92 (2): 7-19

Barnett, H.G. (1953), Innovation the Basis of Cultural Change, New York: McGraw-Hill. 966

Benhabib, J., Spiegel, M.M. (2005), Human capital and technology diffusion, in: Handbook of Economic Growth, 1. pp. 935-

Birkinshaw, J., Bouquet, C., Barsoux, J.-L. (2011), The 5 myths of innovation. MIT Sloan Management Review, 52: 43-50

Carayannis, E., Grigoroudis, E. (2016), Quadruple innovation Helix and smart specialization: Knowledge production and national competitiveness, Foresight and STI Governance, 10 (1): 31-42.

Cornell University, INSEAD, \& WIPO (2016), The Global Innovation Index 2016: Winning with Global Innovation, Ithaca, Fontainebleau, and Geneva.

Dakhli, M., De Clercq, D. (2004), Human capital, social capital, and innovation: a multicountry study, Entrepreneurship \& Regional Development, 16 (2): 107-128.

Danquaha, M., Amankwah-Amoahb, J. (2017), Assessing the relationships between human capital, innovation and technology adoption: Evidence from sub-Saharan Africa, Technological Forecasting \& Social Change, 122: 24-33.

De Bruijn, P., Lagendijk, A. (2005), Regional innovation systems in the Lisbon strategy, European Planning Studies, 13(8): 1153-1172.

Del Giudice, M., Carayannis, E. G., Palacios-Marques, D., Soto-Acosta, P., Meissner, D. (2018), The human dimension of open innovation, Management Decision, 56 (6):1159-1166.

Delgado-Marquez, B. L., Garcia-Velasco, M. (2018), Geographical Distribution of the European Knowledge Base Through the Lens of a Synthetic Index, Social Indicators Research: An International and Interdisciplinary Journal for Quality-of-Life Measurement, 136(2): 477-496.

Dino, A., Sanchez, R. (2017), View Correspondence (jump link) Science, technology and innovation in Europe 2020 strategy and its effects in Spain, Austerity and the Implementation of the Europe 2020 Strategy in Spain: Re-shaping the European Productive and Social Model: a Reflexion from the South, Bruxelles, Bern, Berlin, Frankfurt am Main, New York, Oxford, Wien: Peter Lang AG. Drucker, P.F. (1992), Innowacja i przedsiebiorczosc. Praktyka i zasady, Warszawa: PWE.

Dzemydaite, G., Dzemyda, I., Galiniene, B. (2015), The evaluation of regional innovation systems' efficiency in new member states of European union: A nonparametric approach, Journal of Applied Economic Sciences, 10(3): 317-327.

European Commission (2010). Europe 2020. A strategy for smart, sustainable and inclusive growth, COM (2010), Brussels.

European Innovation Scoreboard, 2017

European Public Sector Innovation Scoreboard (EPSIS) - Methodology report (8 May 2012), Inno Metrics.

Fura, B., Wojnar, J., Kasprzyk, B. (2017), Ranking and classification of EU countries regarding their levels of implementation of the Europe 2020 strategy, Journal of Cleaner Production, 165: 968- 979

Gasz, M., (2015), Kierunki zmian w polityce innowacji w Polsce i Unii Europejskiej, Studia Ekonomiczne. Zeszyty Naukowe Uniwersytetu Ekonomicznego w Katowicach, 214:216-227.

Griffin, R.W. (2007), Podstawy zarzadzania organizacjami, Warszawa: Wydawnictwo Naukowe PWN.

Hecker, A., Ganter, A. (2013), The influence of product market competition on technological and management innovation: Firmlevel evidence from a large-scale survey, European Management Review, 10: 17-33.

Innovation Union Scoreboard, 2010

INSEAD (2011), The Global Innovation Index 2011. Accelerating Growth and Development, Soumitra Dutta (Ed), 2011, France. Kedaitis, V., Kedaitiene, A. (2014), External dimension of the Europe 2020 strategy, Procedia - Social and Behavioral Sciences, 110:700-709.

Kudryavtseva, S.S., Shinkevich, A.I., Ostanina, S.S., Vodolazhskaya, E.L., Chikisheva, N.M., Lushchik, I.V., Shirokova, L.V., Khairullina, E.R. (2016), The methods of national innovation systems assessing, International Review of Management and Marketing, 6(2): 225230.

Mazur-Wierzbicka, E. (2012), Ochrona srodowiska a integracja europejska. Doswiadczenia polskie, Warszawa: Difin.

Nowakowska, A. (2009), Regionalny kontekst procesow innowacji, in: A. Nowakowska (Ed.), Budowanie zdolnosci innowacyjnych regionow (pp.19-42), Lodz: Wydawnictwo Uniwersytetu Lodzkiego.

Palova, D., Vaclavikova, K. (2017), Comparison of Europe2020 implementation process among EU members states, Journal of Applied Economic Sciences, 8(54): 2376-2387.

Papadopoulou, O. (2017), Education and human capital: Driver or challenge for development?, Handbook of Research on Policies and Practices for Sustainable Economic Growth and Regional Development, 21: 40-50.

Paprotny, D. (2016), Measuring central and eastern Europe's socio-economic development using time lags, Social Indicators Research, 127: 939- 957.

Pascu, E., Milea, O.M., Nedea, P.S. (2015), Innovation and design - Two strategic tools for entry into the European economy, Quality - Access to Success, 16: 77-82. 


\section{E. Mazur-Wierzbicka. Human Resources as Fundamental Element Determining the Development of Innovation}

Pater, R., Lewandowska, A. (2015), Human capital and innovativeness of the European Union regions, Innovation, 28(1): 3151.

Prokop, V., Stejskal, J. (2017), Different approaches to managing innovation activities: An analysis of strong, moderate, and modest innovators, Engineering Economics, 28(1): 47-55

Romanowska, E. (2014), Ewolucja polityki innowacyjnej Unii Europejskiej: strategia oraz instrumentarium wsparcia innowacyjnosci w kodeksie integracji z UE, Research on Enterprise in Modern Economy - theory and practice, 2: 5-27.

Roszko-Wojtowicz, E., Bialek, J. (2017), Evaluation of the EU countries' innovative potential - Multivariate approach, Statistics in Transition new series, 18 (1): 167-180.

Schippers M.C., West M.A., Dawson J.F. (2012), Team Reflexivity and Innovation: The Moderating Role of Team Context, Journal of Management, 41 (3): 769-788.

Schumpeter, J.A. (1960), Teoria rozwoju gospodarczego, Warszawa: PWN

Tan, C. L., Nasurdin, A. M. (2010), Human resource management practices and organizational innovation: An empirical study in Malaysia, Journal of Applied Business Research, 2(4):105-115.

Wiatrak, A. P. (2016), Innowacyjnosc w politykach Unii Europejskiej i ich wplyw na kierunki wspierania rozwoju organizacji, Journal of Management and Finance, 2(2): 463-472.

Eurostat. Retrieved from: www. ec.europa.eu/eurostat (12.05.2018).

Є. Мазур-В'єрбіцка, Щецинський університет (Польща).

\section{Трудові ресурси як фундаментальний елемент інноваційного розвитку національної економіки}

Метою статті є проведення систематизації наукових досліджень з питань інноваційного розвитку національної економіки та визначення напрямків ії поліпшення. Розкриті теоретичні основи інноваційного розвитку національної економіки дозволили автору виділити трудові ресурси як один з ключових елементів впровадження інновацій, який безпосередньо впливає на інноваційний напрям розвитку національної економіки та відповідну політику уряду щодо його забезпечення. У статті об'єктом дослідження є країни ЄС, при цьому особлива увага приділяється Польщі. Поставлена мета дослідження зумовила необхідність вирішення таких завдань: оцінити інноваційну активність Польщі порівняно з країнами ЄС за допомогою загальноєвропейського індексу інноваційності (ЗІІ) та глобального індексу інноваційності (ГІІ); визначити вплив трудового капіталу на інноваційний розвиток Польщі порівняно із країнами ЄС на основі ЗІІ та ГІІ; оцінити рівень трудового капіталу в контексті інноваційного розвитку Польщі порівняно з іншими країнами членами ЄС, використовуючи елементи трудових ресурсів, задіяних у сфері наукових досліджень та розробки технологій. Емпіричне дослідження проведено на основі інструментарію статистичного аналізу в період 2010-2016 рр. для 28 країн ЄС (ЄС-28) В дослідженні наголошується, що початковою точкою аналізу обрано рік прийняття стратегії соціально-економічного розвитку ЕС до 2020 року. Аналіз розвитку 3/I та ГІІ демонструє значну диференціацію країн ЄС за рівнем інноваційного розвитку. Так, згідно отриманих результатів дослідження встановлено, що лідерами за рівнем інноваційного розвитку $є$ країни Північної Європи. При цьому аналогічна тенденція спостерігається при оцінці країн ЄС з точки зору розвитку трудового фактору як ключового елементу інноваційного розвитку. Отримані результати дослідження показали, що порівняно із лідерами ЄС у контексті розвитку інновацій та країнами ЄС, які мають аналогічний рівень економічного розвитку (Чеська Республіка, Угорщина та Словенія, тощо) для економіки Польщі характерним є нижчий рівень як інноваційних показників, так і показників трудових ресурсів.

Ключові слова: інновація, трудові ресурси в області наукових досліджень та розробки технологій, країни ЄС, Польща.

Manuscript received: 11.01.2019.

(c) The author(s) 2019. This article is published with open access at Sumy State University. 